\title{
Structural, physical and mechanical changes of cement-bonded particleboards during sudden fluctuations in temperature and moisture
}

\author{
Tomas Melichar ${ }^{1 *} \mathbb{0}$, Jiri Bydzovsky ${ }^{1}$, Jiri Brozovsky ${ }^{1}$ and Miroslav Vacula²
}

\begin{abstract}
The paper presents research focused on behaviour of cement-bonded particleboards with modified composition during sudden changes of temperature and humidity. Four types of boards were made-one control and three modified ones. Finely ground limestone was used as a modifying component in binder. Secondary wood particles made from crushing cuttings of cement-bonded particleboards were used as chips substituent. Two sets of test specimens (1 set $=6$ test specimens) were manufactured. The first set was stored in laboratory conditions. The second set was subjected to 10 cycles of sudden changes of temperature $\left(-20^{\circ} \mathrm{C}\right.$ to $\left.+70{ }^{\circ} \mathrm{C}\right)$ and humidity in accordance with EN 321 (further in the paper referred to as "wet-frost-dry cycle".) After each cycle, dimensions and mass of the test specimens as well as ultrasonic pulse velocity were determined. A detailed analysis of structural changes in boards during cycling was carried out by an optical microscope. After 10 wet-frost-dry cycles were completed, bending strength and modulus of elasticity in bending were determined. The analysis of test results implies a very good relation between change of ultrasonic pulse velocity and width of cracks in the area of interfacial zone between cement matrix and wood particles. This finding also corresponds with dimensional and volumetric changes of the boards. Dependence of bending strength and modulus of elasticity in bending on composition of boards is apparent. Positive influence of secondary spruce chips on dimensional changes of cement-bonded particleboards caused by sudden changes of temperature and humidity was proved. Finely ground limestone contributes to more resistant structure of boards which leads to improved bending properties. Adverse conditions had more considerable influence on bending strength (decrease by $21 \%$ to $26 \%$ ) than on modulus of elasticity in bending (decrease by $12 \%$ to $19 \%$ ).
\end{abstract}

Keywords: Cement-bonded particleboard, Finely ground limestone, Cuttings, Secondary spruce chips, Sudden change, Temperature, Water, Ultrasonic, Microstructure

\section{Introduction}

Resistance of cement-bonded particleboards to action of sudden changes of temperature and humidity is limited by material composition of the boards. From this point of view, properties of spruce chips are very important [1].

\footnotetext{
*Correspondence: melichar.t@fce.vutbr.cz

${ }^{1}$ Brno University of Technology, Faculty of Civil Engineering, Institute

of Technology of Building Materials and Components, Veveri 331/95, 602

00 Brno, Czech Republic

Full list of author information is available at the end of the article
}

By adjusting properties of wood in cement-bonded composite materials it is possible to achieve better properties of the final composite material [2-8]. Composition of cement-bonded particleboards can be modified by both matrix and filler [9-15]. Possibility of using waste from cement-bonded particleboards is presented only in [16]. However, the authors analysed the waste as an alternative component for concrete.

Cuttings without further use are produced during cement-bonded particleboards manufacture. Hence this 
by-product could be characterized as waste. The Company CIDEM Hranice, a.s. (Czech Republic) produces around $5000 \mathrm{t}$ of these cuttings per year [17]. After appropriate treatment of properties of cuttings, this alternative component could be re-used for manufacture of cement-bonded particleboards [17, 18]. Use of these suitably treated cuttings can improve durability of cement-bonded particleboards. Especially, use of secondary chips separated from cuttings could have advantages. Secondary spruce chips had already once gone through the manufacturing process of cement-bonded particleboards. This process includes mineralization by $\mathrm{Ca}$ ions from cement, $\mathrm{Na}_{2} \mathrm{SiO}_{3}$ water glass and $\mathrm{Al}_{2}\left(\mathrm{SO}_{4}\right)_{3} \cdot 18 \mathrm{H}_{2} \mathrm{O}$ with elevated temperature and pressure. Cell structure of secondary chips is therefore mostly filled by components of cement matrix (portlandite, $\mathrm{C}-\mathrm{S}-\mathrm{H}$, ettringite, etc.). Presence of hydration products of cement matrix penetrated inside lumens and gel formation on surface of wood was proved [19]. Sodium silicate also penetrates to the lumina of the wood cells, which leads to the improved flexural modulus of rupture and decrease in moisture sorption of the treated wood. Sodium silicate located in wood structure blocks the pits connecting the two wood cells. This phenomenon significantly contributes to decrease in moisture migration into the wood structure [20]. Thus the structure of the secondary chips, particularly their surface, is denser with decreased absorption and less susceptible to volume changes caused by increased humidity. Furthermore, content of hemicellulose is lower than in case of primary chips. It is caused by dissolubility of hemicellulose in alkaline environment of cement matrix. The most of the hydroxyl groups in hemicellulose is responsible for approximately $37 \%$ of total water sorption in wood [21]. Compared to primarily used chips, properties of such secondary chips are considerably stabilized. Improvement of properties of raw and stabilized wood through various methods is also proved [22-28]. Therefore, the secondary spruce chips are expected to show better resistance to changes of temperature and humidity.

Properties and behaviour of cement-bonded particleboards in adverse conditions have been studied by many authors, for example [29-34]. Nevertheless, none of the authors has dealt with resistance of cement-bonded particleboards containing secondary spruce chips from cuttings of these boards. Most publications present research focused mainly on fluctuation of air humidity or its combination with increased temperature. It also means that boards were subjected to different course of cycles compared to procedure described in EN 321. The standard describes relatively aggressive method with sudden change of temperature $\Delta \Theta=90^{\circ} \mathrm{C}$ and change of humidity from water bath to dry environment. Particleboards containing wood change their structure and parameters considerably during such fluctuations of environment.

In terms of characterizing behaviour of cementbonded particleboards in adverse environment in detail, it is appropriate to support standard methods by nondestructive techniques. Ultrasonic pulse method is used mainly for evaluation of changes in inner structure of some building materials. This technique is mostly applied for tests of freeze-thaw resistance or for evaluation of quality - for determination of dynamic Young's modulus of elasticity or compressive strength of concrete. The procedure is codified in Czech and foreign technical standards for concrete and some building materials (natural stone, concrete, refractory materials, bricks, etc.). However, currently there is no technical standard describing application of ultrasonic pulse method for evaluation of properties of cement-bonded particleboards. Problems of using this method for examination of properties of wood based panels and particleboards are presented [35-49]. The surface density can be used to quality control of particleboards with different structures [47]. However, the authors did not analyse changes of properties of boards caused by wet-frost-dry cycles described in EN 321 .

The objective of the research presented in this paper is the analysis of cement-bonded particleboards during sudden changes in temperature and humidity using conventional test techniques supported by non-destructive ultrasonic pulse method. Attention is paid to assessing changes of dimensions, mass, volume, mechanical properties and structure of cement-bonded particleboards with modified composition exposed to wet-frost-dry cycles (according to EN 321).

\section{Materials}

Cement-bonded particleboards were made on the production line of the company CIDEM Hranice, a.s. The process was in accordance with standard conditions of industrial manufacture. Manufacturing process used standard mixture for boards (only REF further in the text). Composition of this mixture is as follows: $50 \%$ of cement, $18 \%$ of spruce chips, $30 \%$ of water and $2 \%$ of hydration additions (sodium water grass and aluminium sulphate). This composition is commonly used by CIDEM Hranice, a.s. Considering results of current and previous research $[17,18,50]$, three modified compositions were designed:

- REF-reference mixture, standard production of cement-bonded particleboard.

- LI10-10\% of cement was replaced with finely ground limestone.

- SW07-7\% of spruce chips was replaced with secondary chips 
- L10/S07-10\% of cement was substituted with limestone and $7 \%$ of primary chips with secondary chips (Table 1)

Compatibility of spruce wood and cement matrix is at high level. Spruce usually does not cause problems during cement hydration [51]. The ions exchange between cement and wood in presence of water can lead to a strong bond between the two materials due to the improved anchoring of the binder $[19,51]$. Mechanical bonding and mechanical interlocking [52] such as chemical bonding [53] of wood and cement matrix occur. The interlocking is caused by growing crystals of cement matrix into cell structure of wood. Hydroxyl bridges and hydrogen bonding are significant during bonding cement matrix and wood when the matrix is bonded to the cellulose fibres [54]. Diffusion of cement molecules (based on $\mathrm{Ca}, \mathrm{Si}$, etc.) into the cell wall of wood chips was proved [55]. Mineral components of matrix penetrate deeply into the wooden structure when lumens, rays, etc., are partially filled by these hydration products [56]. However, the compatibility of the cement matrix and spruce chips is partially limited by some inhibitors contained in spruce wood. The main problem could be presence of hemicellulose which is dissoluble in alkaline environment, i.e. cement matrix $(\mathrm{pH}=12.5)$. Hemicellulose diffuses into the cement paste $[51,57]$. This leads to significantly reduced forming of the main products of cement hydration (portlandite and $\mathrm{C}-\mathrm{S}-\mathrm{H}$ phases and gels) $[58,59]$. Unreacted cement grains are surrounded by acicular

Table 1 Composition (\%) of designed mixtures-reference and modified by limestone and secondary spruce chips

\begin{tabular}{lllll}
\hline Component & REF & LI10 & SW07 & L10/S07 \\
\hline Cement & 50 & 45 & 50 & 45 \\
Limestone & - & 5 & - & 5 \\
Spruce chips_-primary & 18 & 18 & 16.74 & 16.74 \\
Spruce chips-secondary & - & - & 3.53 & 3.53 \\
Water & 30 & 30 & 30 & 30 \\
Admixtures & 2 & 2 & 2 & 2 \\
\hline
\end{tabular}

hydrates in presence of hemicellulose [60]. Especially, reaction of $\mathrm{C}_{3} \mathrm{~A}$ and $\mathrm{C}_{3} \mathrm{~S}$ is inhibited. Amount of unreacted cement clinker grows with increasing extractive content. This leads to strength reduction of the cementwood composite [61]. The composition of cement is also important due to the compatibility between wood and cement with an effect on mechanical properties [62, 63]. Several procedures were used to eliminate aforementioned adverse effect of hemicellulose during cementbonded particleboards:

- pre-treatment of spruce chips;

- use of chemical substances;

- treatment of the particleboards during manufacturing process.

Pre-treatment of wood is important to reduce the content of extractives in chips. Therefore, open air drying was applied to the used spruce chips when hemicellulose amount was reduced to range of $0.15-0.25 \%$. Acceptable content of hemicellulose in wood particles for cementbonded particleboards production is up to $0.5 \%[64,65]$. Sodium water glass and aluminium sulphate were used to regulate the hydration process of cement in spruce chips presence. These chemical substances accelerate forming of cement matrix, which partially eliminate negative effect of hemicellulose. Also these substances contribute to mineralization process of spruce chips (penetrate to cell structure of wood). Positive effect of curing cementbonded particleboards (with spruce chips) by elevated temperature $\left(40-60{ }^{\circ} \mathrm{C}\right)$ during production is obvious [66]. Therefore, the particleboards were thermally treated at elevated temperature, $45^{\circ} \mathrm{C}$.

Properties of the cement used are presented in Table 2. Figure 1 shows the curve of distribution and particle size of the cement.

Chemical composition and other significant properties of the limestone Kotouč Štramberk VMV15-F are shown in Table 3. Dominant component in crystalline phase is calcite, further aragonite, traces of magnesite and silica. The curve of distribution and particle size of finely ground limestone is presented in Fig. 1.

Table 2 Properties of the cement CEM II 42,5 R

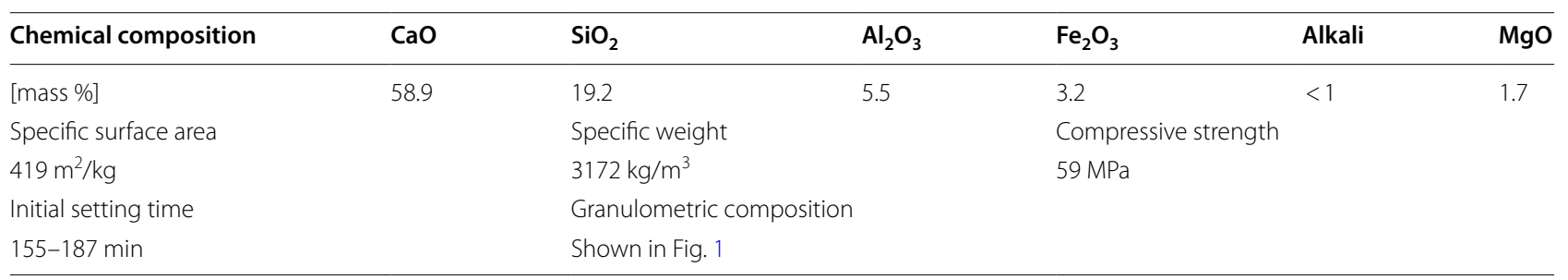




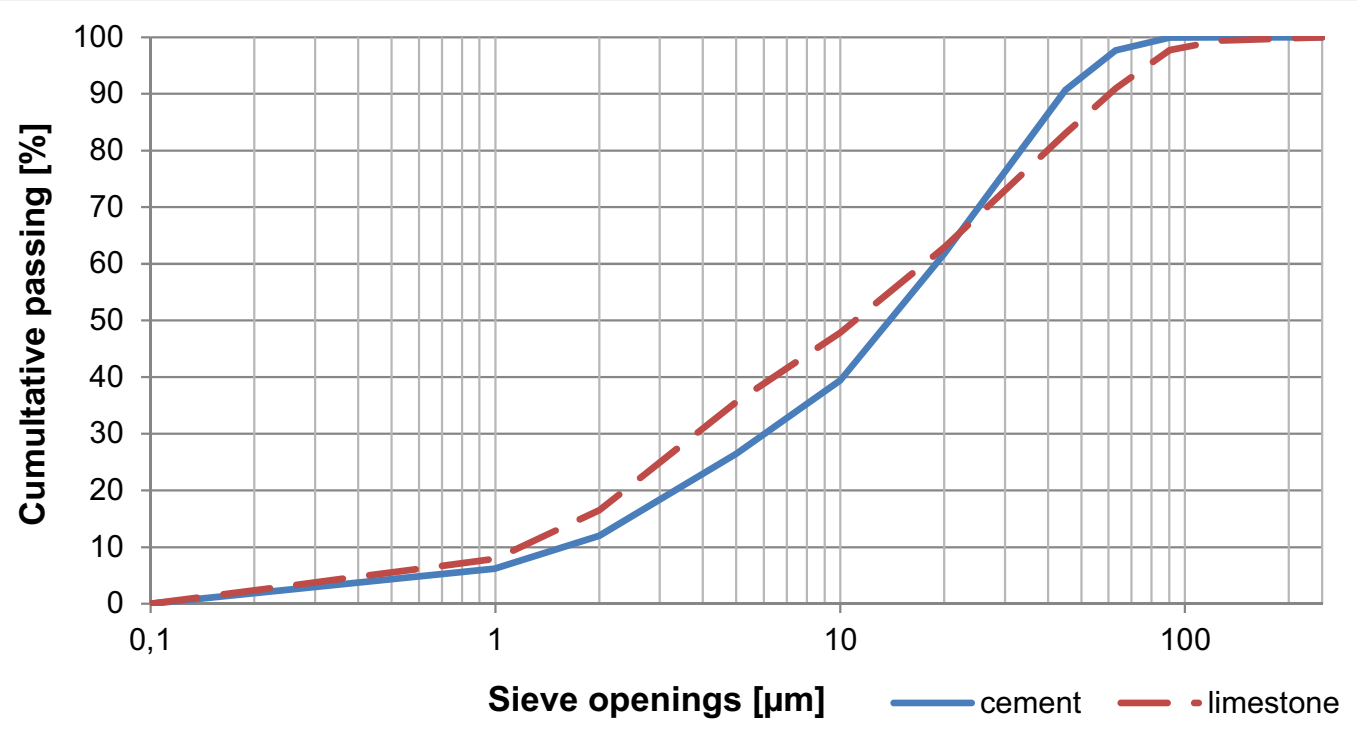

Fig. 1 Granulometric curve of cement CEM II/A-S 42,5 R and limestone VMV15-F

Table 3 Properties of the limestone VMV15-F

\begin{tabular}{|c|c|c|c|c|c|c|c|}
\hline Chemical composition & $\mathrm{CaO}$ & $\mathrm{CO}_{2}$ & $\mathrm{SiO}_{2}$ & $\mathrm{Al}_{2} \mathrm{O}_{3}$ & $\mathrm{Fe}_{2} \mathrm{O}_{3}$ & Alkali & $\mathrm{MgO}$ \\
\hline [mass \%] & 52.4 & 41.6 & 1.2 & 0.3 & 0.1 & 0.06 & 0.6 \\
\hline Specific surface area & & Specific weight & & & Granulometric curve & & \\
\hline $487 \mathrm{~m}^{2} / \mathrm{kg}$ & & $2697 \mathrm{~kg} / \mathrm{m}^{3}$ & & & see Fig. 1 & & \\
\hline
\end{tabular}

Mineralogic composition (XRD analysis)

Calcite, aragonite, traces of magnesite and quartz

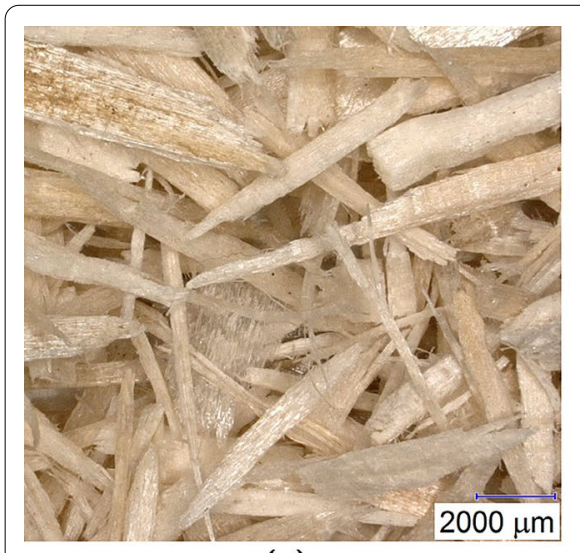

(a)

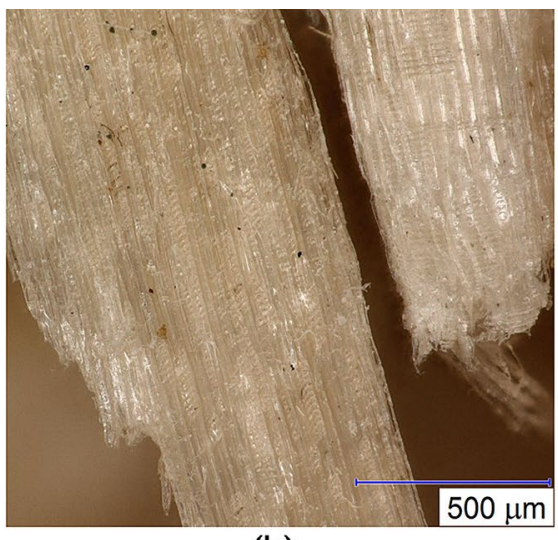

(b)

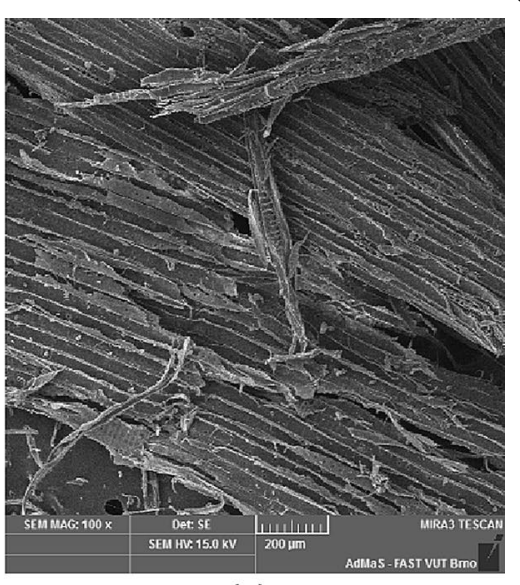

(c)

Fig. 2 Structure of primary spruce chips for manufacture of cement-bonded particleboards: a magnification 10x and $\mathbf{b}$ magnification 70x images from optical microscope Keyence VHX-950F; c image from electron microscope Tescan MIRA3 XMU (magnification 100x) 
Table 4 Properties of the primary and secondary spruce chips

\begin{tabular}{lcll}
\hline $\begin{array}{l}\text { Particle size } \\
{[\mathbf{m m}]}\end{array}$ & $\begin{array}{l}\text { Density } \\
{\left[\mathbf{k g} / \mathbf{m}^{3}\right]}\end{array}$ & $\begin{array}{l}\text { Bulk density } \\
{\left[\mathbf{k g} / \mathbf{m}^{3}\right]}\end{array}$ & $\begin{array}{l}\text { Water } \\
\text { absorption } \\
{[\%]}\end{array}$ \\
\hline $0-8.0$ & 420 & 90 & 196.3 \\
$0.5-1.0$ & 1160 & 460 & 54.7 \\
$1.0-2.0$ & 1190 & 480 & 49.3 \\
\hline
\end{tabular}

Spruce chips contain dominant proportion of particles within the interval $0.25 \mathrm{~mm}$ to $4 \mathrm{~mm}$, in total $79 \%$. Particles below $0.25 \mathrm{~mm}$ are in the proportion of $7 \%$. The rest are particles from 4 to $8 \mathrm{~mm}$, i.e. $14 \%$. Figure 2 shows structure of primary chips used for manufacture of cement-bonded particleboards. Properties of the primary spruce chips are shown in Table 4.
Cuttings (Fig. 3a) are produced during adjusting particleboards to the required shape and size. Production of cuttings has a rising trend which Fig. $3 \mathrm{~b}$ shows. Particle size distribution was modified in a jaw crusher. Required groups of particles were separated. Separation was carried out on the basis of results presented in [17]. Particles selected for further research were those with the highest contents of TOC (total organic carbon, see [17]), i.e. content of wood. Particles with dimensions from 0.5 to $2 \mathrm{~mm}$ were used. In this way, secondary spruce chips (Fig. 4) were gained. Table 4 shows properties of secondary spruce chips. Specific surface area of the chips was not considered regarding to small amount of substitution.

Density of secondary spruce chips is higher than that of primary chips. Relatively small amount of the primary chips will be substituted-7\% of the primary chips, which is approx. $3.5 \%$ of the whole particleboard mixture.

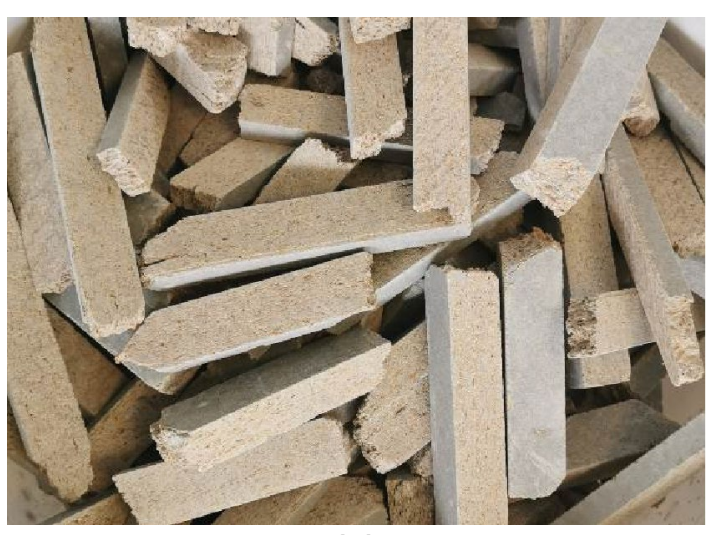

(a)

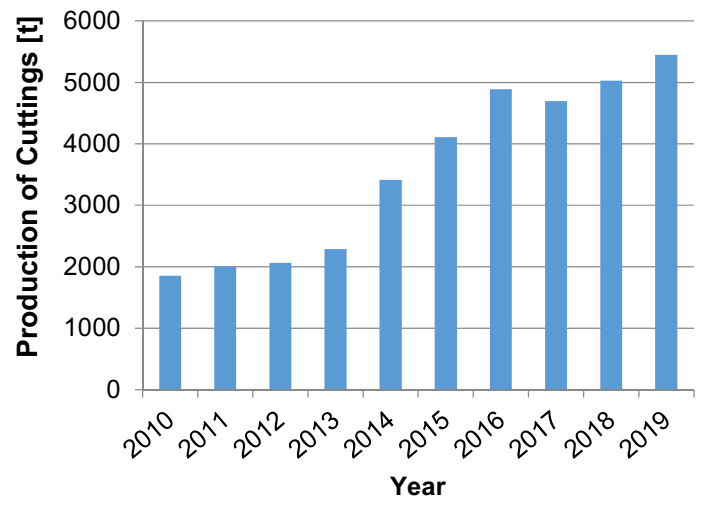

(b)

Fig. 3 Cuttings (by-product) from manufacture of cement-bonded particleboards: a sample taken in the manufacturing plant; $\mathbf{b}$ production of cuttings by CIDEM Hranice a.s. in the years 2010 to 2019

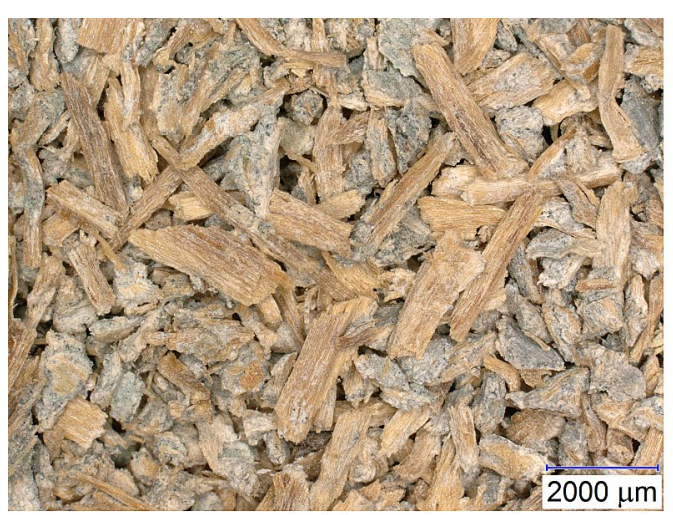

(a)

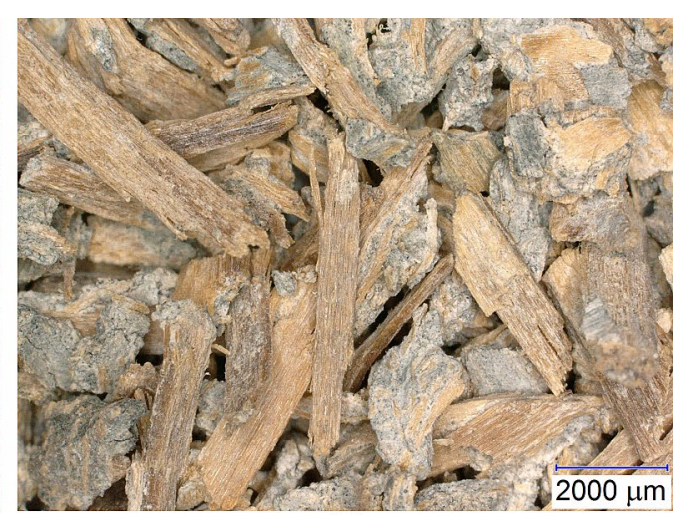

(b)

Fig. 4 Crushed cuttings from production of cement-bonded particleboards: separated secondary chips a 0.5 to 1.0 mm (magnification $10 x$ ) b 1.0 to $2.0 \mathrm{~mm}$ (magnification 10x) 
Therefore, a significant effect on the final density of produced particleboards is not expected.

Comparison of parameters of primary and secondary chips implies that primary spruce chips have considerably higher water absorbing capacity and lower density compared to secondary chips. Lower water absorption of the secondary chips indicates better resistance to volume changes related to humidity and temperature fluctuations.

Results of the analyses stated in [17], including assessment of structure (Figs. 4 and 5), show that secondary chips contain residua of cement matrix. Products of cement matrix are bonded to the surface of the secondary chips, which Fig. 5 shows.

Grains from 1 to $2 \mathrm{~mm}$ contain even a certain number of small clusters of matrix and chips, which are presented in Fig. 4b. This can lead to enhanced chips resistance to humidity and temperature changes. On the other hand, negative impact could be proved during manufacturing process of cement-bonded particleboards. Secondary chips with residua of cement matrix are less squeezable during pressing compared to primary chips. Different flexibility of secondary chips could result in less compact or dense structure and even slight decreased strength of boards. Figure 6 shows microstructure of secondary chips. Cell structure of wood is partially filled with products of cement hydration.

Secondary chips dose added into raw material was 1:2-fraction $0.5 \mathrm{~mm}$ to $1.0 \mathrm{~mm}: 1.0 \mathrm{~mm}$ to $2.0 \mathrm{~mm}$. To achieve required "moist" consistence (suitable for pressing), water dose was around 30\% (by weight). However, amount of water was modified according to measured moisture of spruce chips dosed into the mix for production of boards. To achieve stabilization of wood chips and improve hydration processes, doses of additions based on sulphates and soluble glass were added into the mix.

\section{Methods}

Cement-bonded particleboards REF, LI10, SW07 and L10/S07 were made with standard manufacturing process in the plant CIDEM Hranice, a.s. in the Czech Republic. After 21 days of maturing, test specimens were prepared in accordance with EN 634-1 [67], EN 634-2 [68], EN 323 [69] and EN 310 [70]. Based on the analysis with ultrasonic pulse method, longer size of test specimen was selected $-380 \mathrm{~mm} \times 50 \mathrm{~mm} \times 12 \mathrm{~mm}$. For each individual set, 12 test specimens were made -6 control specimens for comparison and 6 specimens for cycling in accordance with EN 321 [71]. After 28 days of maturing in the production conditions in CIDEM Hranice, a.s., test specimens were transported to the Institute of Technology of Building Materials and Components, Faculty of Civil Engineering, Brno University of Technology. Test specimens matured further in the environment with $75 \%$ relative humidity and constant temperature $(20 \pm 2){ }^{\circ} \mathrm{C}$. Under such conditions, the reference test specimens were matured for 11 months and specimens intended for wet-frost-dry for about 9 months. Test specimens intended for exposition in adverse conditions were then subjected to cycling in accordance with [71]. All specimens were then placed in the environment with relative humidity $(65 \pm 5) \%$ and temperature $(20 \pm 2){ }^{\circ} \mathrm{C}$. Testing of all physical-mechanical properties of all test specimens of cement-bonded particleboards were carried out at the age of 12 months. Sequence of individual steps and times, i.e. from manufacture of boards to final testing, is shown in Fig. 7.

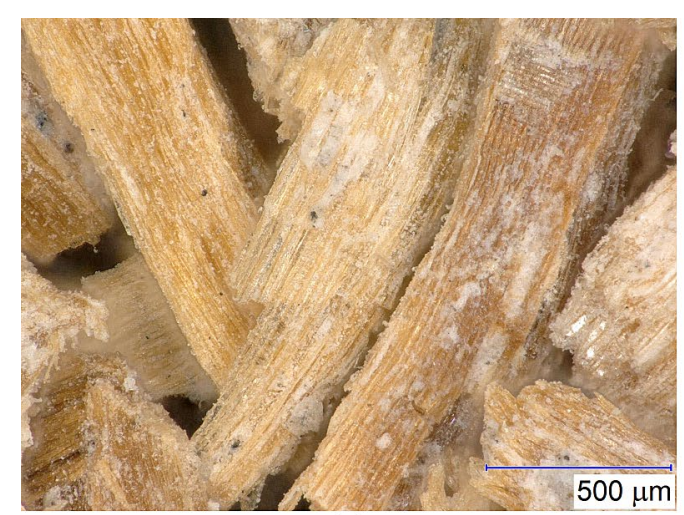

(a)

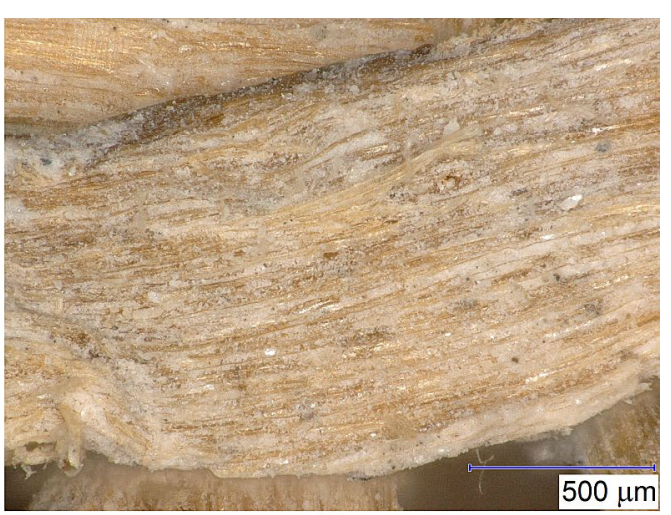

(b)

Fig. 5 Structure of separated chips from crushed cuttings from production of cement-bonded particleboards (images from optical microscope): a 0.5 to $1.0 \mathrm{~mm}$ (magnification $70 \mathrm{x}$ ) b 1.0 to $2.0 \mathrm{~mm}$ (magnification $70 \mathrm{x}$ ) 


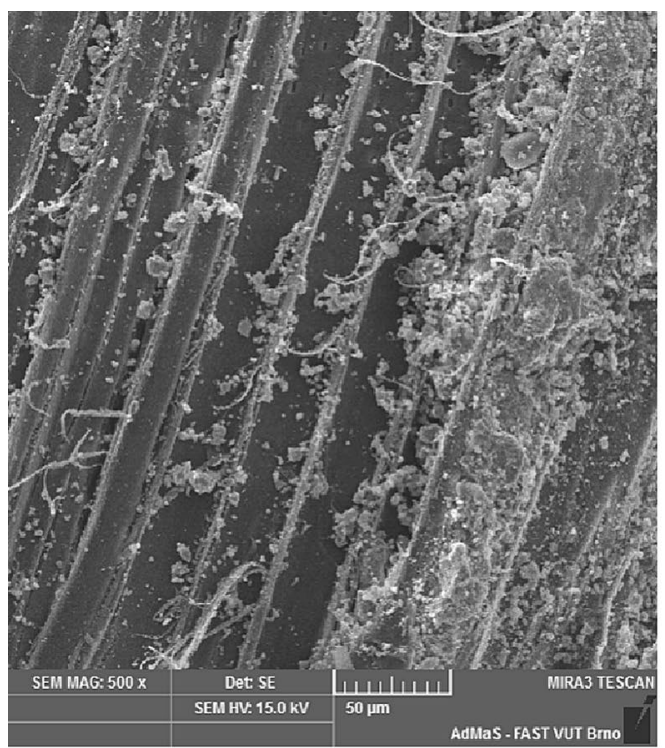

(a)

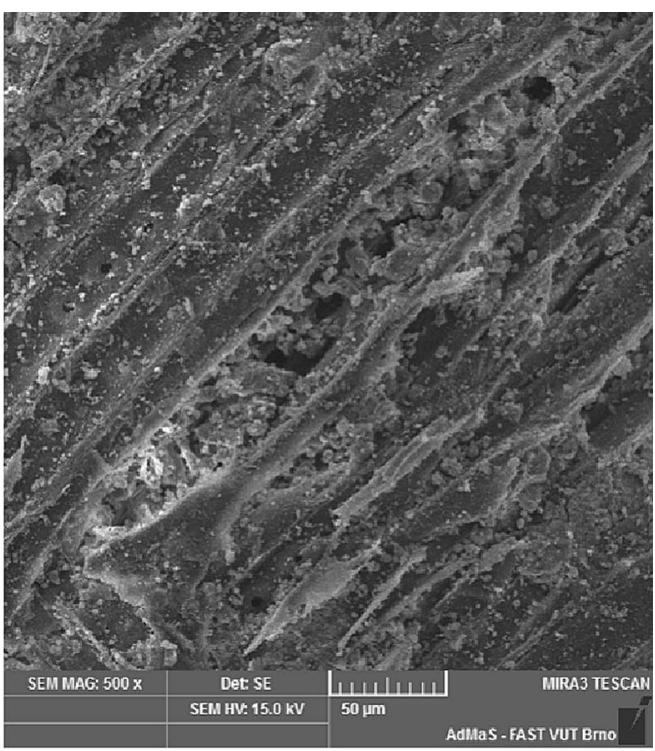

(b)

Fig. 6 Detail of chips separated from crushed cuttings of cement-bonded particleboards (images from electron microscope): a $0.5 \mathrm{~mm}$ to $1.0 \mathrm{~mm}$; b 1.0 tot $2.0 \mathrm{~mm}$

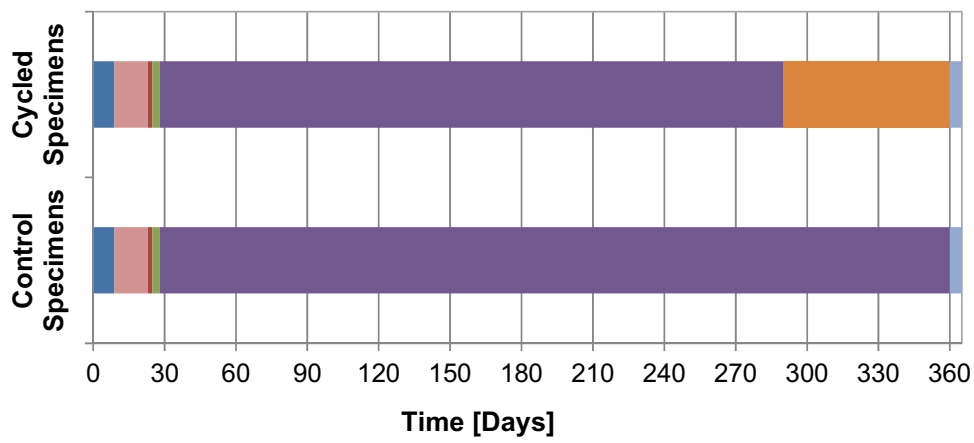

- Production of boards CIDEM Hranice, a.s.

- Ageing of boards - CIDEM Hranice, a.s.

- Test specimen preparation - CIDEM

- Transport to BUT laboratory

- Ageing of specimens at BUT - RH 75\%

- Cycling under conditions EN 321

- Testing of density, strength and modulus

Fig. 7 Timeline of presented research

\section{Shock action of temperature and humidity}

To assess long-term durability from the point of view of sudden changes of temperature and humidity, environment defined in EN 321 [71] was selected. Course of the cycles is shown in Fig. 8.

All phases of the cycle follow each other without a break. Freezing and drying apparatuses with sufficient volume are set to the required temperature in advance so that placing of test specimens does not change set conditions. In this way, sudden changes of exposition environment are assured (of both temperature and humidity). Thermal gradient between the phase of freezing and drying reaches $90^{\circ} \mathrm{C}$, which is a relatively aggressive change of environment if presence of frozen water is considered. In total, 10 wet-frost-dry cycles were repeated.

\section{Monitoring of properties during cycles}

After each test cycle was completed (Fig. 8), dimensions and weight were determined and changes in the structure of cement-bonded particleboards were observed. Changes in the structure were determined with ultrasonic pulse method-process of measurement was in accordance with EN 12504-4 [72]. Ultrasonic pulse velocity (in accordance with [72]) and dynamic Young's modulus of elasticity (in accordance with ČSN 731371 [73]) were determined. 


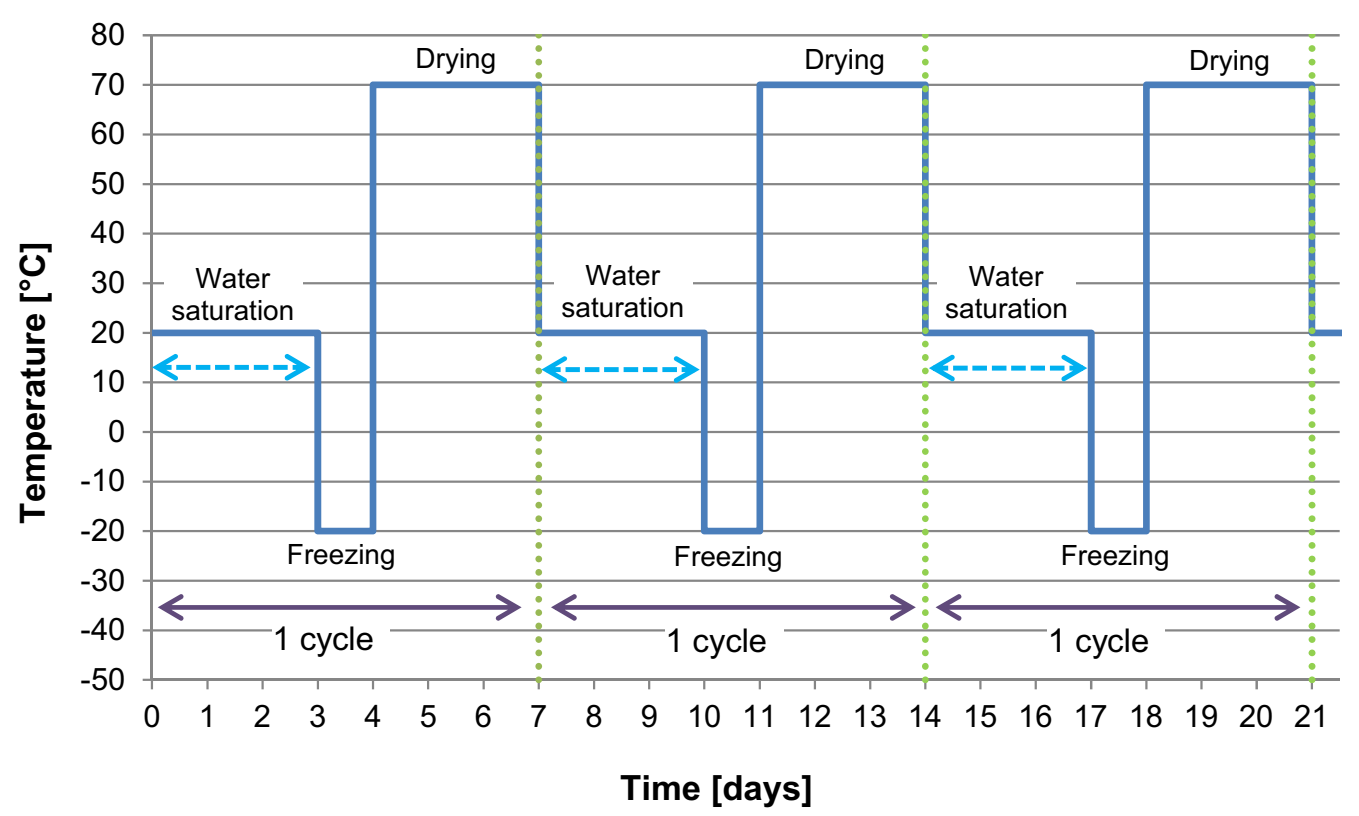

Fig. 8 Course of sudden changes of temperature and humidity (wet-frost-dry cycles)

Measurements were taken with the apparatus for determination of arrival time of the pulse PUNDIT LAB with accuracy $0.1 \mu \mathrm{s}$ and natural frequency of the transducers $150 \mathrm{kHz}$. The boards were tested with ultrasonic pulse always after drying phase. For acoustic bond, silicon binding agent with constant elasticity was used because of high water absorbing capacity of the surface of the analysed material. Using materials stated in ČSN EN 12504-4 [72] could have a negative impact on repeated measurements taken at identical points.

Measurements of test specimens with dimensions $380 \mathrm{~mm} \times 50 \mathrm{~mm} \times 12 \mathrm{~mm}$ were carried out by semidirect transmission. Direct transmission in longitudinal and transversal direction of samples with standardly used sounders is problematic (natural frequency is from 54 to $150 \mathrm{kHz}$ ) because thickness of the sample is $12 \mathrm{~mm}$ and minimal diameter of the sounder is $25 \mathrm{~mm}$; moreover, surface on these areas is not compact. When sounding is carried out in the direction of thickness of a test specimen, the sounder touches tested surface by all its area.
However, it is problematic to achieve reliable results at such a short distance.

Determination of the interval of passage of ultrasonic pulse was carried out on two diagonally located symmetrical measuring bases. The reason for this arrangement was capturing changes in the whole volume of the test specimen. Figure 9 presents scheme of transmission of the test specimens. Positions for attaching actuator and sensor on test specimens were marked with accuracy $0.5 \mathrm{~mm}$. Locations of attachment are shown in Fig. 10 . Before each ultrasonic measurement, length of measuring base $d_{1}, d_{2}$ were determined. Subsequently, transit times $T_{1}, T_{2}$ were determined.

Ultrasonic pulse velocity was calculated in accordance with relation (1) [72]:

$$
V=L / T,
$$

where $V$-ultrasonic pulse velocity $[\mathrm{km} / \mathrm{s}] ; L$-length of measuring base $[\mathrm{mm}] ; T$-transit time $[\mu \mathrm{s}]$.

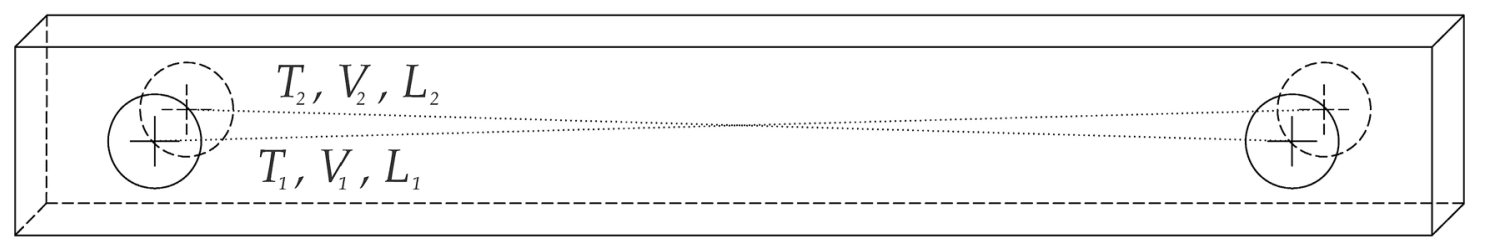

Fig. 9 Scheme of determination of length of measuring basis $\left(L_{1}, L_{2}\right)$, time $\left(T_{1}, T_{2}\right)$ and velocity $\left(V_{1}, V_{2}\right)$ of passage of ultrasonic pulses through the test specimens 


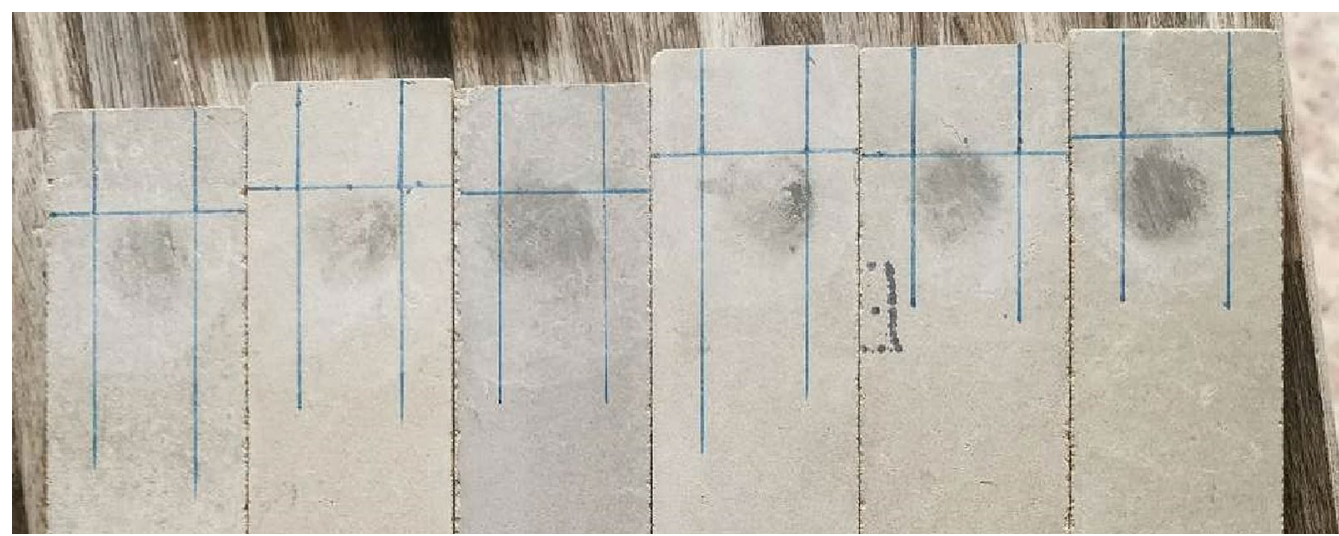

Fig. 10 Representative SE of test specimens after finishing the 4th cycle in accordance with EN321 and after determination of time of passage of ultrasonic pulse

Dynamic Youngs modulus of elasticity $E_{U}$ was calculated in accordance with the relation (2) [73]:

$$
E_{U}=V^{2} \times D,
$$

where $E_{U}$-dynamic Young's modulus of elasticity from ultrasonic pulse method [MPa]; $D$-density $\left[\mathrm{kg} / \mathrm{m}^{3}\right]$.

Further, after the end of each cycle, changes of structure of cement-bonded particleboards were analysed in detail with the optical microscope Keyence VHX-950F. Attention was paid to areas of the boards which can be described as those with the highest probability of failure occurrence due to sudden changes of environment.

\section{Testing of parameters after finished cycles}

After 10 wet-frost-dry cycles were completed, both sets of specimens were placed in identical conditions in accordance with EN 310 [70] and EN 323 [69] so that weight and dimensions were stabilized. Density in accordance with EN 323 [69], bending strength and modulus of elasticity in bending according to EN 310 [70] were determined. Arrangement of the test of strength and modulus of elasticity corresponds to three-point flexure. For each set (=6 specimens), average value of analysed parameter was determined.

\section{Results and discussion}

\section{Dimensional, volume and mass stability}

Based on determined dimensions, shown in Fig. 11, it can be stated that changes in longitudinal direction (length) and transversal direction (width) are smaller than changes of thickness.

Length is characterized by contraction due to sudden changes of temperature and humidity. Contraction in range of $0.14 \%$ (SW07) to $0.17 \%$ (LI10) after 10 cycles was determined. The most significant decrease of length can be observed as early as after the first cycle, when the contraction is between $0.13 \%$ and $0.18 \%$. Boards with secondary chips (SW07 and L10/S07) showed the best results. Development of changes roughly corresponds with findings in [31]. The authors determined contraction of cement-bonded particleboards (at the age of 360 days) due to changes of humidity by $0.16 \%$ to $0.17 \%$. Nevertheless, development of measured values is slightly different. This is caused by differences of conditions. Changes of relative humidity at constant temperature can be characterized as slower compared to wet-frost-dry cycling.

Changes in the transversal direction of the particleboards are shown in Fig. 11b. Width reduction was determined between -0.11 and $-0.18 \%$ up to the fifth cycle. Then, more steep growth followed and values are stabilized at $0.08 \%$ to $0.19 \%$. Expansion in the direction of width was observed after 10 cycles. Changes in transversal direction are smallest in case of boards SW07. Data of relevant research (technical literature, etc.) were not found. Thus, comparing the results with findings of other authors is not possible.

The most marked changes due to humidity and temperature fluctuations shown in Fig. 11c occur in the direction of thickness. Fibres orientation in wood material and the chips themselves in the cement matrix play a significant role. Changes of thickness of boards can also be influenced by tension in spruce chips from manufacture of cement-bonded particleboards (pressing and elevated temperature). This residual tension in wood (contained in the composite) originates in the method of manufacturing process of composites [74]. After the first cycle, thickness was reduced by $0.19 \%$ to $0.31 \%$ The third wet-frost-dry cycle is characterized by changes of thickness close to $0 \%$. Then, with following cycles, thickness 


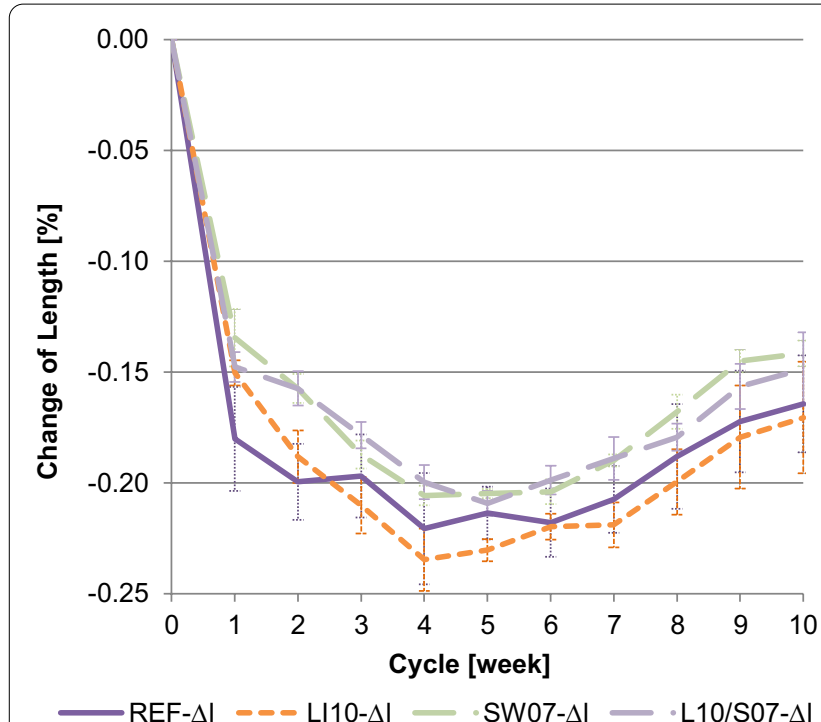

(a)

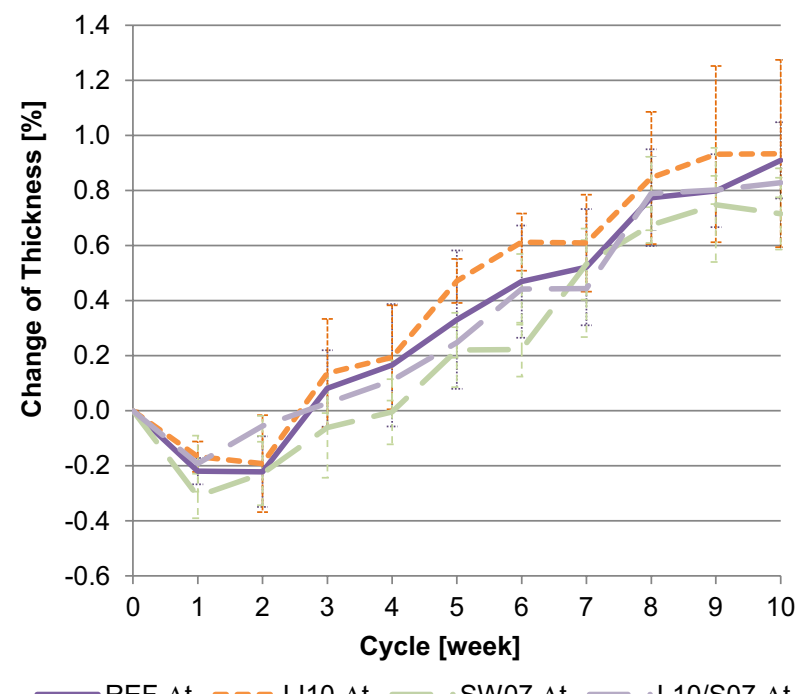

(c)

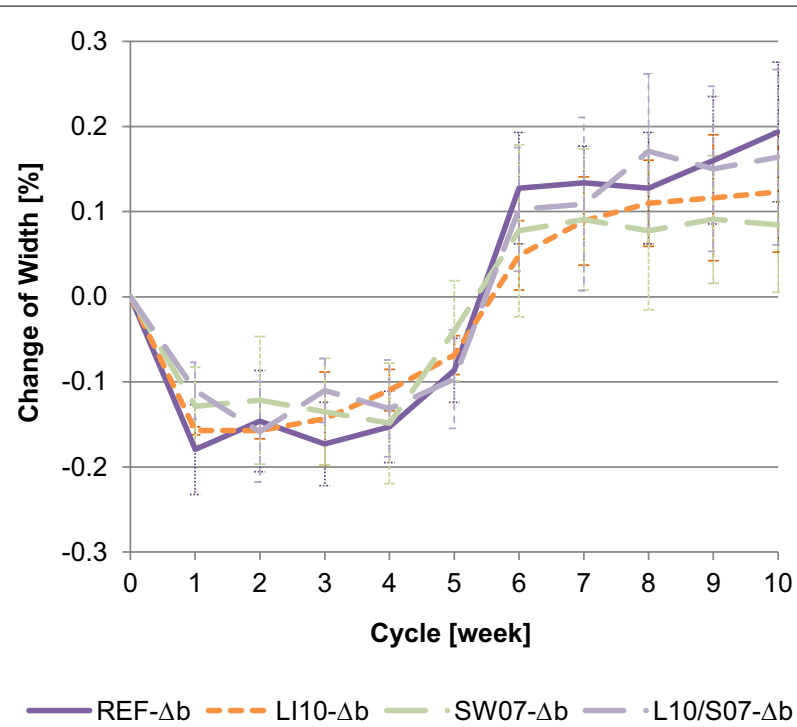

(b)

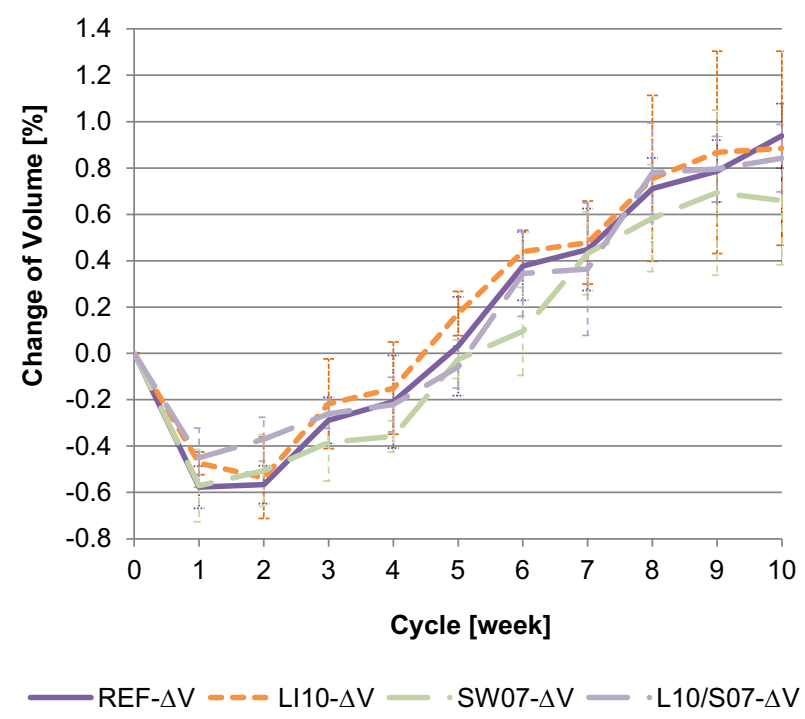

(d)

Fig. 11 Comparison of a length, $\mathbf{b}$ width, $\mathbf{c}$ thickness and d) volume changes of cement-bonded particleboards exposed to wet-frost-dry cycling according to EN 321

grew to the level of $0.72 \%$ to $0.93 \%$. Boards SW07 showed the smallest change of thickness.

Comparison of the results shown in Fig. 11c with findings [34] implies that development of thickness changes is similar. However, final values are considerably higher. Irreversible growth of thickness by approx. 15\% was determined after the seventh wet-dry cycle [34]. Course of cycling and composition of the particleboards (wastepaper and saw dust) are the reason for such a significant difference. That is why contraction did not occur
[34]. Growth of thickness up to the fifth wet-dry cycle is inter alia caused by loss of coherence of cement matrix and chips due to shrinking of wood material during drying [34]. Changes of thickness practically stabilize after the fifth wet-dry cycle [34]. On the contrary, thickness shown in Fig. 11c keeps growing up to the tenth wetfrost-dry cycle.

The trend of volume curves is shown in Fig. 11d. This trend is practically an identical copy of thickness changes. During the first and second cycle, volumetric 


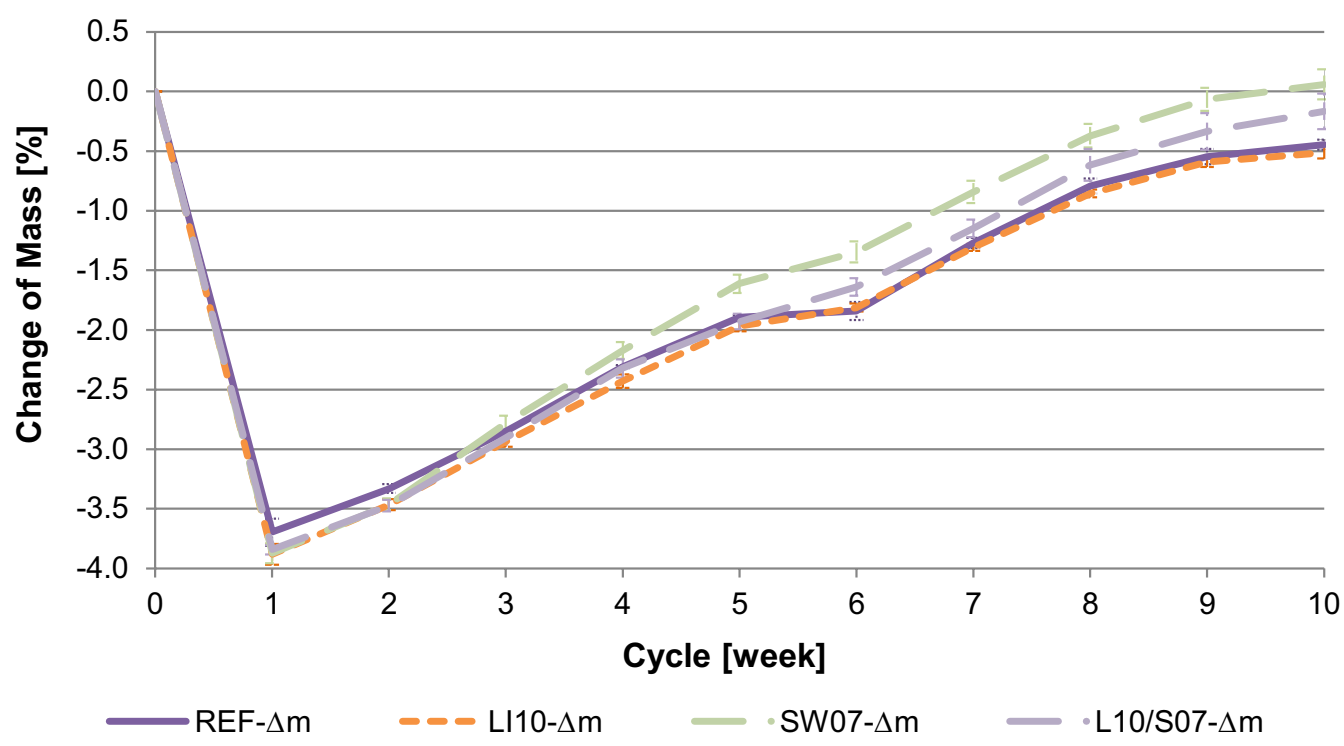

Fig. 12 Comparison of mass changes of cement-bonded particleboards exposed to wet-frost-dry cycling according to EN 321

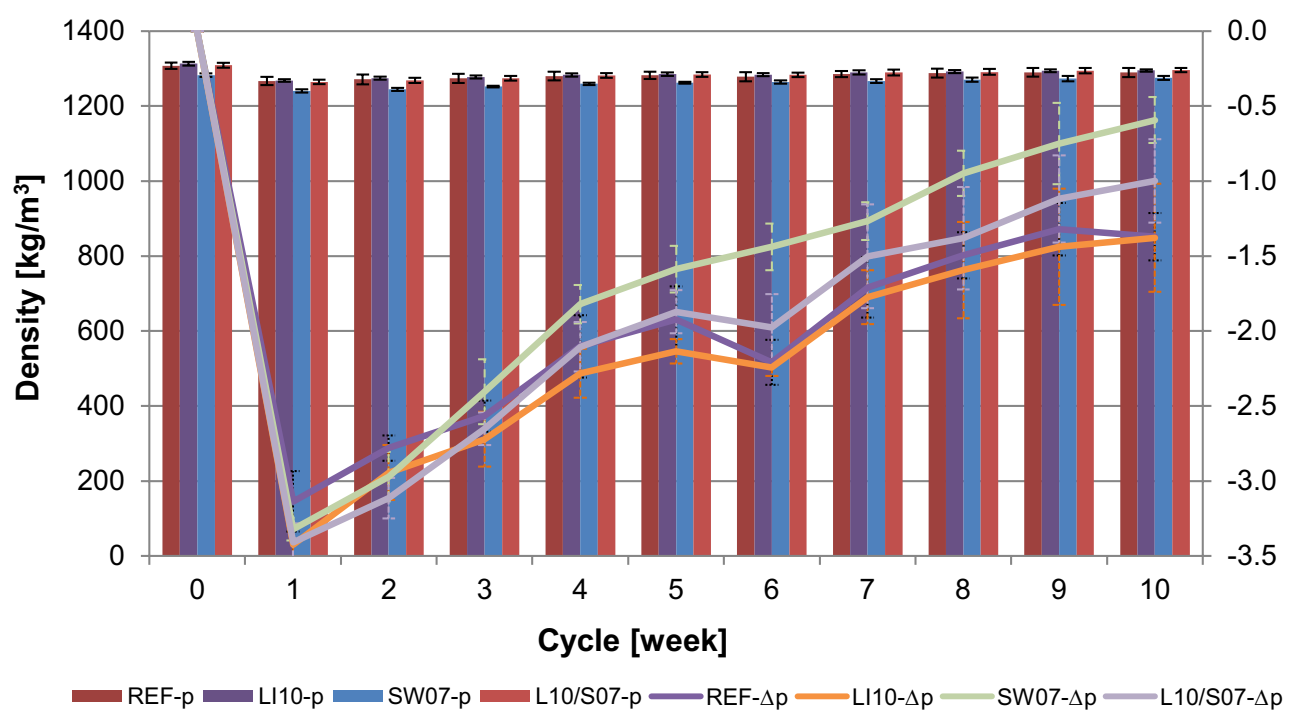

Fig. 13 Comparison of density changes of cement-bonded particleboards exposed to wet-frost-dry cycling according to EN 321

shrinkage is up to $0.6 \%$. After the tenth cycle, volume is characterized by expansion by $0.61 \%$ to $0.91 \%$. Boards SW07 show the least volumetric changes. Better resistance to volumetric changes of boards SW07 and L10/S7 can be inter alia explained by different releasing of water soluble carbohydrates and leachable substances. Secondary chips had already been stabilized and smaller amount of leachable substances can be expected [75]. Influence of dry-wet cycles on volumetric changes of wood is presented in [24]. The authors confirm that gradual growth of volume of aspen and birch wood occurs as a consequence of wet-dry cycles. No relevant findings of other authors concerning volumetric changes of cement-bonded particleboards due to wet-dry cycles or wet-frost-dry cycles were found. An interesting possibility of enhancing dimensional and volumetric stability could present partial substitution of primary chips with inorganic materials-for example aggregate based on sintered fly ash, which is analysed in detail in [76]. Volumetric stability could 
also be improved by materials with similar base, as presented in [77].

Better resistance of boards SW07 to wet-frost-dry cycling is related to different mechanism between cement matrix and secondary or primary chips. The first phase of wet-frost-dry cycle is characterized by water saturation of the particleboards. Secondary chips are more stabilized with lower water absorption as presented in Table 4 . Therefore, smaller pressure acts to the cement matrix which surrounds the secondary chips. Particleboards are subjected to frost during the second phase of wet-frostdry cycle. Thus, the water absorbed in the chips increases volume and pressure on the surrounding matrix. Primary chips contain larger amount of water and higher pressure on adjacent matrix occurs. Last phase of wet-frost-dry cycle is characterized by a rapid increase in temperature from $-20{ }^{\circ} \mathrm{C}$ to $70{ }^{\circ} \mathrm{C}$. The pressures are released and volume of the chips decreases. Due to the amount of absorbed water, shrinkage of the secondary chips is lower. Primary chips are subjected to more pronounced contraction. Therefore, more frequent failures are formed in ITZ (internal transition zone) of primary chips and cement matrix.

Resistance of the particleboards to wet-frost-dry cycles is also affected by surface structure of the chips. Secondary chips have more closed surface, or cell structure. Therefore, products of cement matrix do not penetrate into the cell structure of secondary chips in the same way as that of primary chips. Bond of secondary chips with matrix could be negatively affected, i.e. weakened. Regarding better volume stability of secondary chips, slightly weakened bond may not be reflected in dimensional or volume changes. However, due to wetfrost-dry exposure, more noticeable decrease could occur in case of strength characteristics.

Mass changes are shown in Fig. 12. Due to wet-frostdry cycles, weight decreases by $3.7 \%$ to $3.8 \%$ straight after the first cycle. After the tenth cycle, changes of weight are close to $0 \%$. SW07 boards show slight growth of weight by $0.06 \%$. Other types of boards show slight reduction of weight from 0.2 to $0.5 \%$. Considerable decrease in weight in the initial phase of wet-frost-dry cycles can be ascribed to elimination of leachable substances from wood material [75]. Development of weight approximately corresponds with results of the research presented in [31]. Compared results show certain similarities in spite of difference in cycle characteristics. Cementbonded particleboards showed decrease in weight in the first phase by approx. $2.1 \%$, while after cycling, the boards showed increase in weight by approx. 2.7\% [31]. Rapid decrease in weight and subsequent gradual growth can be ascribed to the combination of several phenomena taking place at the same time. First, elimination of leachable substances takes place [24, 75]. Then, hysteresis grows gradually [31]. Growth of weight could also be supported by crystallization of some of the products of cement matrix with gradual growing of these new forms.

Changes of density shown in Fig. 13 could also be expressed by determination of dimensions and weight. Trend of density changes is very similar to trend of mass changes. Boards SW07 showed the least reduction of weight after 10 wet-frost-dry cycles; by $0.05 \%$. Boards REF and LI10 can be characterized by decrease by approx. $1.3 \%$.

Secondary chips are characterized by higher density when compared to primary chips. However, this factor did not affect the final density of the particleboards with modified composition. This is due to the smaller amount of secondary chips. $7 \%$ of the primary chips were substituted, which is $3.53 \%$ of the total composition of the particleboard mixture.

\section{Ultrasonic impulse analysis Ultrasonic pulse velocity}

Results of determining propagation of ultrasonic pulse velocity from beginning to the end of wet-frost-dry cycles of individual types of boards are shown in Fig. 14. Ultrasonic pulse velocity before beginning of wet-frostdry cycles was between $2.401 \mathrm{~km} / \mathrm{s}$ and $2.438 \mathrm{~km} / \mathrm{s}$ and corresponds roughly with the results in [42]. However, boards with considerably lower density, $713 \mathrm{~kg} / \mathrm{m}^{3}$ and $718 \mathrm{~kg} / \mathrm{m}^{3}$, were studied. Ultrasonic pulse velocity after the $10^{\text {th }}$ wet-frost-dry cycle was between $2.351 \mathrm{~km} / \mathrm{s}$ and $2.385 \mathrm{~km} / \mathrm{s}$.

Based on the results presented in Fig. 14, it is obvious that in case of semi-direct transmission method, particleboard analysing in various (symmetrical) directions is important. Thus, the whole volume of the particleboard can be analysed exactly and in detail. Velocity can change in different directions because the board structure may not be homogeneous. All non-homogeneous areas and defects of the structure may become worse because of exposing boards to the wet-frost-dry cycles. An interesting fact is that slightly more distinct differences between velocities V1 and V2 shown in Fig. 14a, b can be observed on boards REF and LI10. This confirmed the assumption of different development of ultrasonic pulse velocity on individual measuring bases.

Results shown in Fig. 15 imply that all types of the analysed boards show considerable decrease in ultrasonic pulse velocity after the first wet-frost-dry cycle, which corresponds to decrease in density shown in Fig. 13 and which is confirmed by changes of dimensions and weight. This decrease can be explained by more significant changes in the structure of the cement-bonded particleboards. After the first wet-frost-dry cycle, differences in 


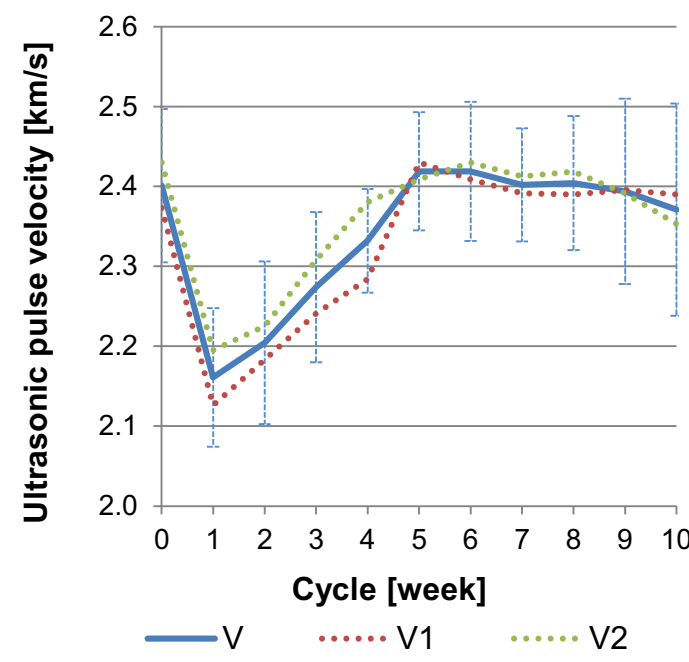

(a)

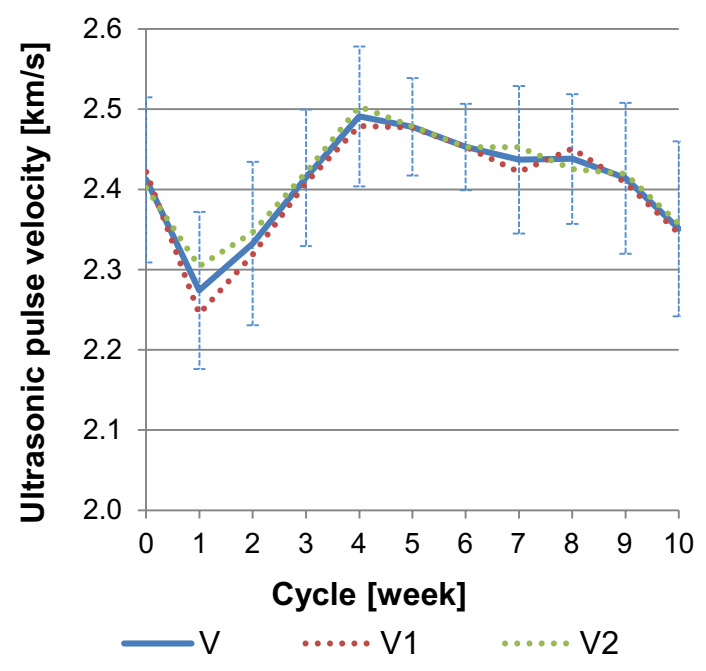

(c)

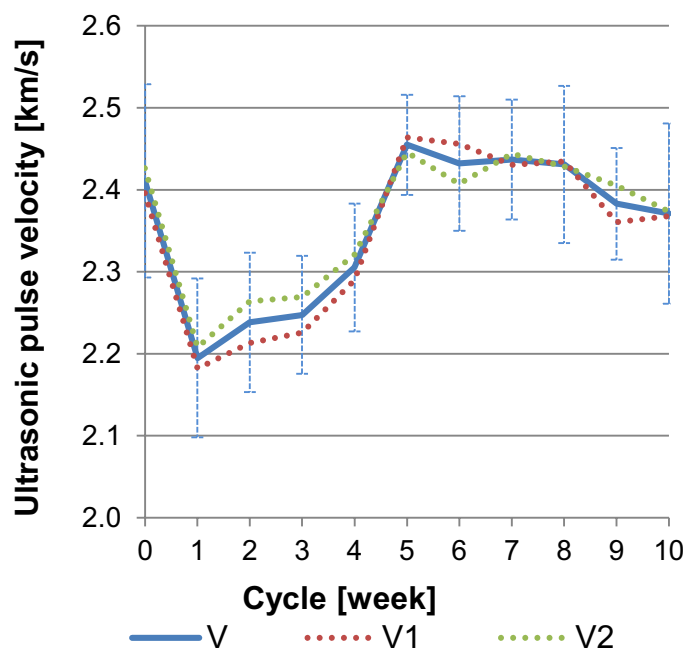

(b)

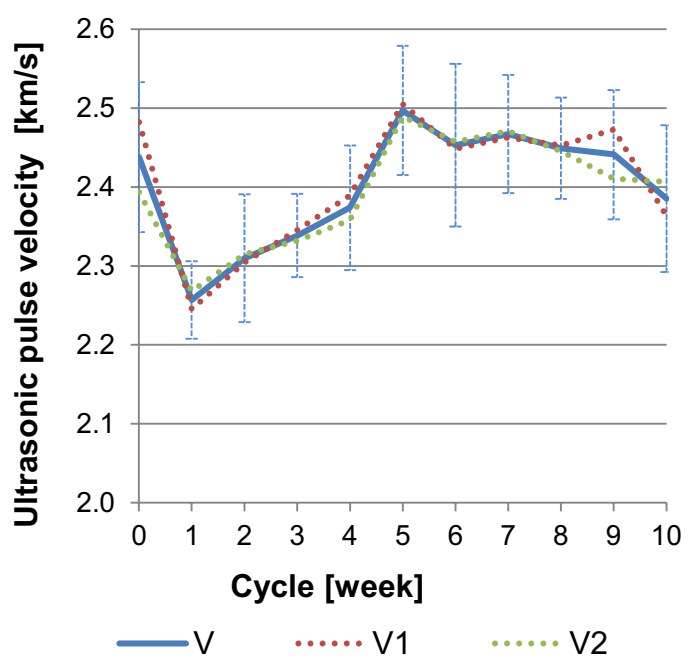

(d)

Fig. 14 Ultrasonic pulse velocity in cement-bonded particleboards exposed to environment according to EN 321 a REF; b LI10; c SW07; d L10/S07

velocity of individual types of boards are more distinct. Decrease in velocity after the first wet-frost-dry cycle is less noticeable on boards SW07 and L10/S07.

From 1st to 5th wet-frost-dry cycle, the boards show increase in ultrasonic pulse velocity. Most of test specimens achieved maximal ultrasonic pulse velocity after 5 th cycle. The highest velocities after 4th or 5th cycle were observed on boards SW07 and L10/S07. Maximal values of velocities are roughly comparable to values before the wet-frost-dry cycling. Increase in velocity from 2 nd to 5 th cycle can be explained by compaction of the board structure. This is in relation with the fact that most of decomposable substances had already been leached from chips, and with the hysteresis of wood. Denser structure also relates to leaching of ions from cement matrix, while the crystalline phases gradually grow during further cycling. During compaction of the board structure, no detectable failures of bond on the interface between cement matrix and wood chips occur, neither in the structure of individual components. Compaction of the structure is confirmed by increasing of density, as shown in Fig. 13.

From 5 to 10th wet-frost-dry cycle, the boards show constant decrease in ultrasonic pulse velocity. This 


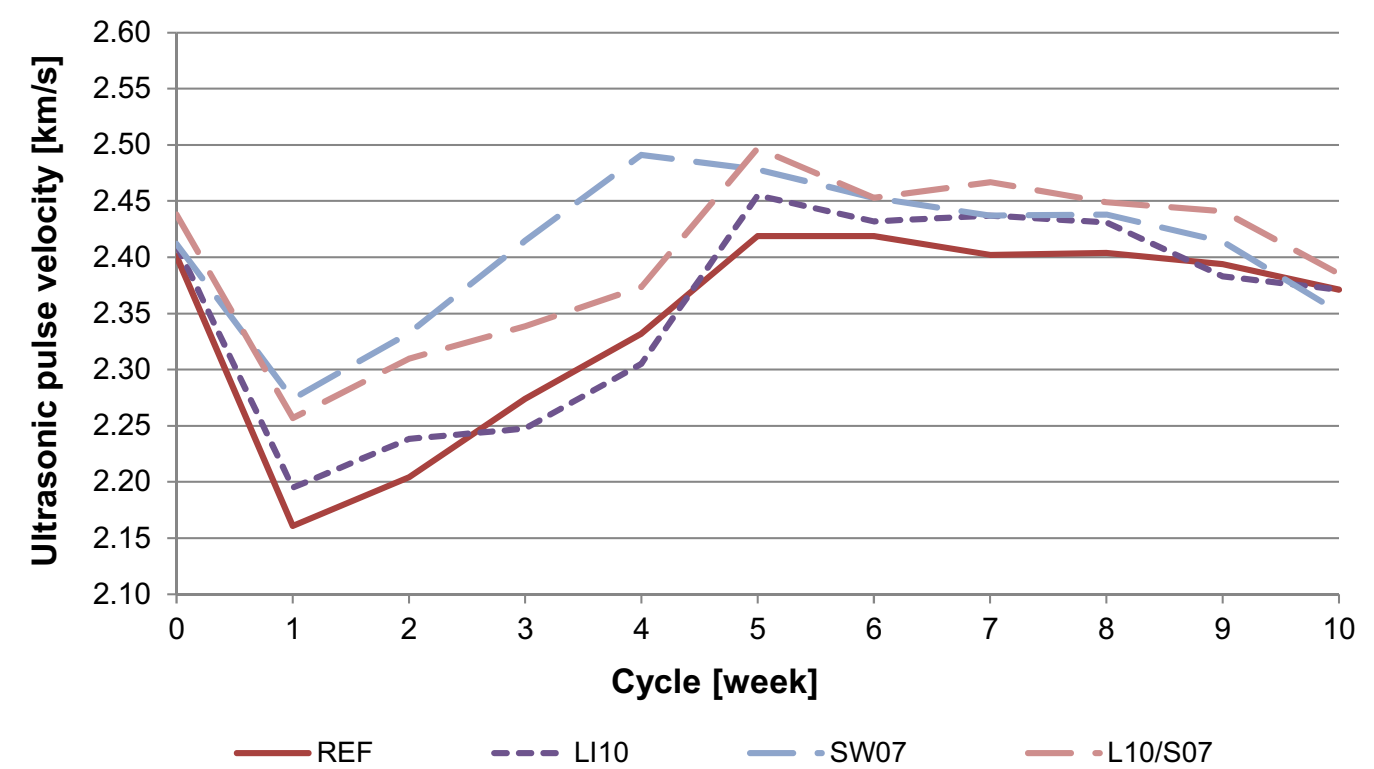

Fig. 15 Comparison of ultrasonic pulse velocity in cement-bonded particleboards exposed to wet-frost-dry cycles in accordance with EN321

decrease can be observed in spite of compaction of the structure and constantly increasing density shown in Fig. 13. Decrease in ultrasonic speed velocity is related to damage to inner structure of cement-bonded particleboard as a consequence of ongoing wet-frost-dry cycles. Gradually, coherence and bond of the interface between cement matrix and wood chips or in the structure of individual components is deteriorated. During this phase of exposition, influence of structural damage is more apparent during sudden changes of temperature and humidity than the aspect of gradual compacting of the structure. Ultrasonic pulse velocity between 5 and 10th wet-frostdry cycle presented in Fig. 15 shows smaller differences between the analysed types of boards (compared to velocity between 1 st and 5 th cycle).

Decrease in ultrasonic pulse velocity after 10 wetfrost-dry cycles (related to ultrasonic pulse velocity before cycling) was between -1.2 and $-2.5 \%$. If decrease in ultrasonic pulse velocity after finished cycling is related to maximal value (i.e. after 4 th of 5 th wetfrost-dry cycle), the value of decrease is in the interval from -2.0 to $-5.6 \%$.

Initial ultrasonic pulse velocity (before exposition) is nearly identical for boards REF, LI10 and SW07. Boards L10/S07 showed slightly higher velocities. Boards SW07 and L10/S07 (with secondary chips) showed slightly more distinct decrease in ultrasonic pulse velocity $(-2.5 \%$, and $-2.2 \%)$ after all 10 wet-frost-dry cycles compared to board REF and LI10 (- $1.2 \%$ and $-1.7 \%$ ).

It was found out that density changes shown in Fig. 13 and ultrasonic pulse velocity, presented in Fig. 15, correspond only partially. It is an important finding, because some authors studied relation between density and ultrasonic pulse velocity in cement-bonded particleboards. Some scientists [40] found very strong dependencies. Effect of particle size of the analysed material is significant when density is low. However, none of the authors used ultrasonic pulse method for boards exposed to wet-frost-dry cycles. Ultrasonic pulse method was used for evaluation of only those boards which were stored in standard laboratory environment. The findings of research presented in this paper imply that cementbonded particleboards show different behaviour (during exposure in various environments) with regard to relation between conventional and non-destructive test method.

\section{Dynamic Young's modulus of elasticity}

Values of dynamic Young's elasticity modulus presented in Fig. 16 were between $7.46 \mathrm{GPa}$ and $7.78 \mathrm{GPa}$ before wet-frost-dry cycling. After finishing 10th cycle, average values of dynamic Young's modulus of elasticity were determined, in the interval from 7.05 GPa to 7.38 GPa.

Decrease in dynamic Young's modulus of elasticity after 10 wet-frost-dry cycles was determined in the range of $-3.8 \%$ to $-5.5 \%$. If decrease in ultrasonic pulse velocity after finished cycling is related to maximum (achieved after 4th or 5th wet-frost-dry cycle), the values of decrease are in the range of $-3.8 \%$ to $-9.9 \%$. Boards REF showed nearly identical values of dynamic Young's elasticity modulus before cycling and after finishing 5th wet-frost-dry cycle. 


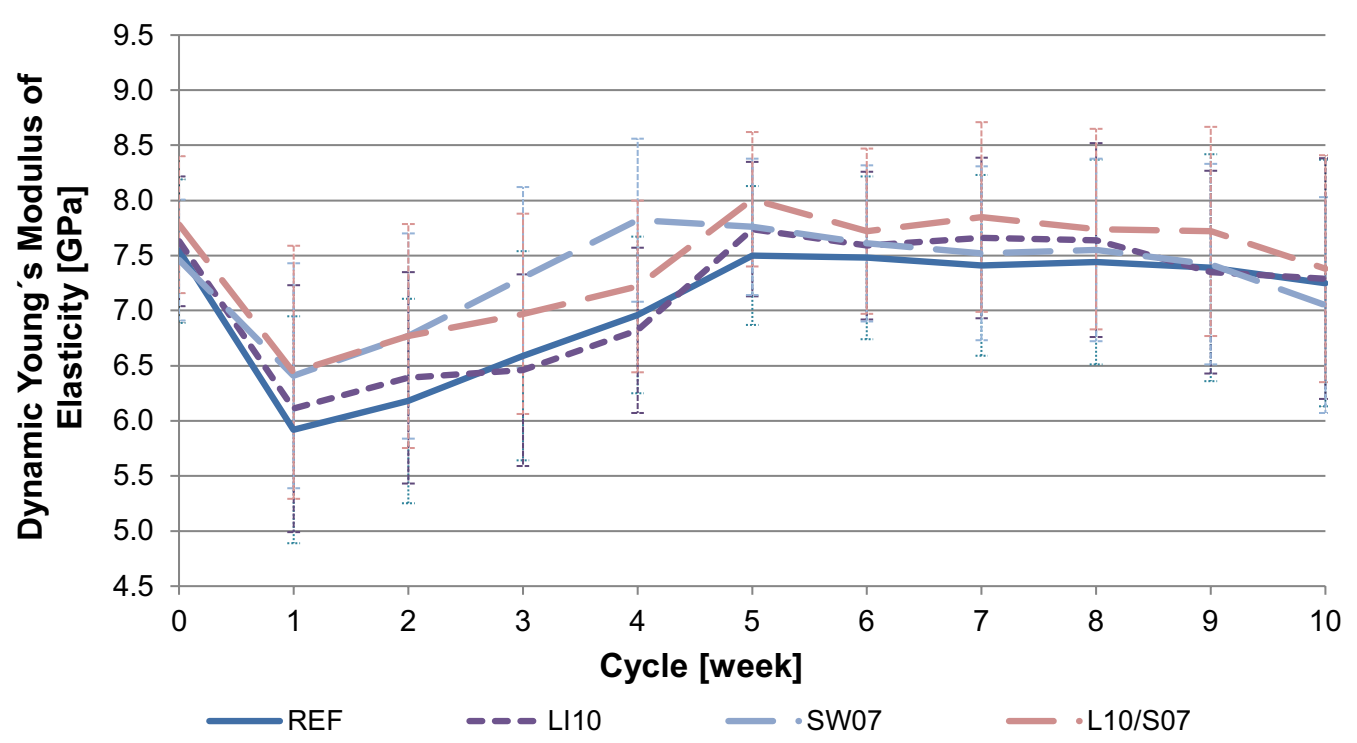

Fig. 16 Comparison of dynamic Young's elasticity modulus of cement-bonded particleboards exposed to wet-frost-dry cycling in accordance with EN321

Development of dynamic Young's elasticity modulus reflects development of ultrasonic pulse velocity. However, slight differences can be found in development of velocity and modulus shown in Figs. 15 and 16. Density is considered for calculation of dynamic Young's elasticity modulus. Therefore, density affects final values of modules and thus smaller variations between curves of individual types of boards are observed. This is valid for development of curves between 1st and 5th wet-frostdry cycle.

\section{Mechanical parameters}

Modification of composition of cement-bonded particleboards had positive effect on bending strength. Comparison of bending strength is presented in Fig. 17. Boards REF showed $11.5 \mathrm{~N} / \mathrm{mm}^{2}$ and modified boards are characterized by strength from 12.2 to $12.7 \mathrm{~N} / \mathrm{mm}^{2}$. There are two reasons for the positive effect. Finely ground limestone contributes to hydration reaction of cement when nucleation and growth of $\mathrm{C}-\mathrm{S}-\mathrm{H}$ crystals occur [78-80]. Boards modified by limestone are characterized

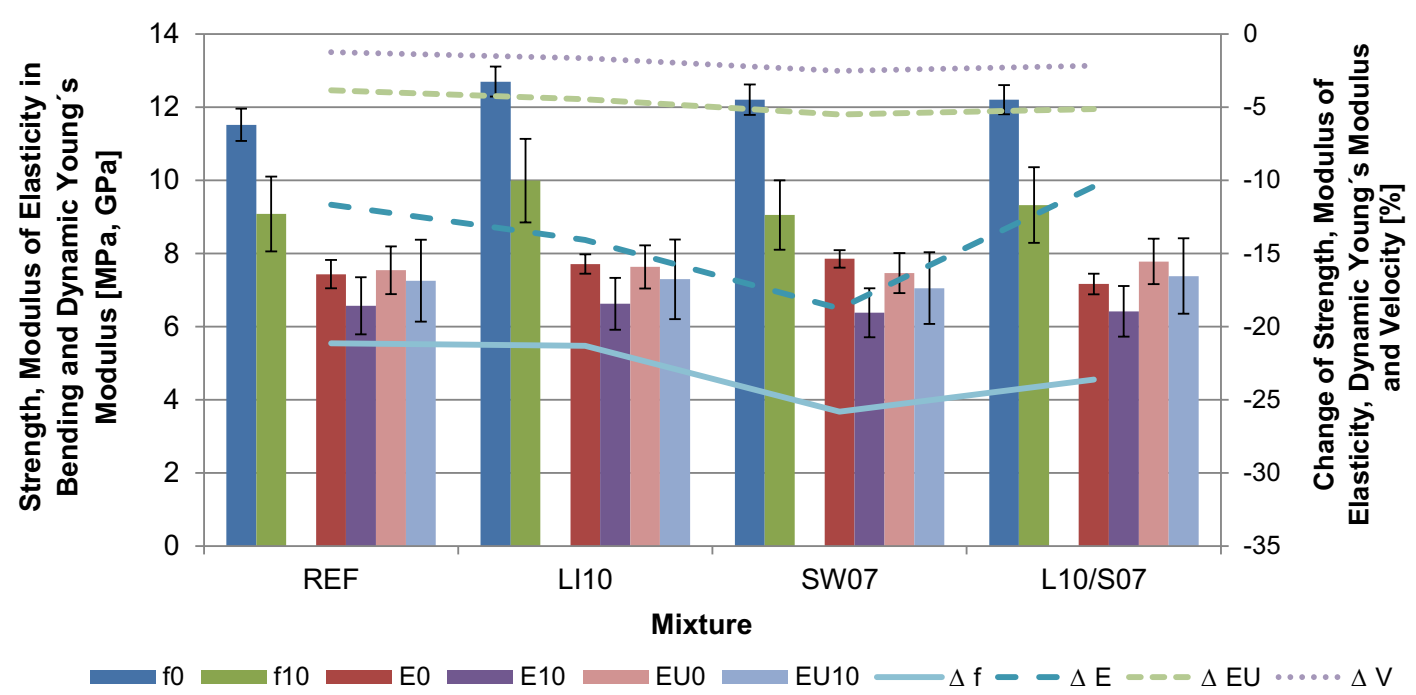

Fig. 17 Comparison of changes of bending strength, modulus of elasticity and dynamic Young's modulus of elasticity before and after 10 wetfrost-dry cycles 
by a slightly higher density, which is obvious from Fig. 13 . Denser and more cohesive structure of cement matrix modified by limestone causes higher strength of boards LI10 and L10/SW07. Furthermore, boards SW07 contain once already mineralized secondary chips. These secondary chips are almost three times denser than the primary chips. Structure of the secondary chips is stabilized more effectively. Therefore, the secondary chips are characterized by higher strength, which positively affects strength characteristics of the modified boards.

Wet-frost-dry cycling had more negative effect in spite of higher initial bending strength of boards with modified composition. Bending strength of cement-bonded particleboards decreased by $21.3 \%$ to $25.8 \%$ by cycles. Bending strength of REF boards decreased by $21.1 \%$. The considerable positive effect of finely ground limestone on properties of cement-bonded particleboards was confirmed by determined values of bending strength and modulus of elasticity in bending.

Secondary chips have a positive effect on dimensional or volumetric stability and changes of mass or density shown in Figs. 11, 12, and 13. However, slightly more distinctive reductions of strength and modulus of elasticity were observed. It is important that strength and modulus of elasticity in bending of all the tested boards after 10 wet-frost-dry cycles are above $9 \mathrm{~N} / \mathrm{mm}^{2}$. All boards fulfil requirements of EN 634-2 as regards minimal bending strength and modulus of elasticity in bending even after exposition to wet-frost-dry cycling.

The results show a need for complex approach to solving problems of explanation of phenomena taking place in cement-bonded particleboards during their exposition to wet-frost-dry cycles. Even though boards SW07 and L10/S07 showed better stability of dimensions and volume (as confirmed by the ultrasonic pulse method), their resistance to bending strain is slightly lower. Length of wood chips affects resistance of boards to wet-frostdry cycling. Secondary chips have smaller dimensions and different shape compared to primary chips, which are shown in Figs. 2, 4 and 5. However, this factor had no effect on the values of strength and modulus of control specimens (without wet-frost-dry cycling). Secondary chips are gained through treatment in a jaw crusher, where bond of individual particles is damaged. Possibility that the structure of some particles used in the boards was already slightly damaged cannot be excluded. Their structure could be further damaged during board pressing (as a part of the production process). This may not have shown on dimensional and volumetric changes. However, failures could gradually grow due to wet-frostdry cycles and this could explain decrease in bending properties.

\section{Evaluation of relation between non-destructive analysis and mechanical properties}

Decrease in ultrasonic pulse velocity, or dynamic Young's elasticity modulus, which is calculated from the values before and after cycling, characterizes development of changes in the structure of cement-bonded particleboards. However, these values differ from the trend of decrease in strength and modulus of elasticity shown in Fig. 17.

More appropriate (and more objective) way is assessment of final changes in the structure compared to maximal value after exposition to wet-frost-dry cycles, which is presented in Fig. 18. In this particular case, it is

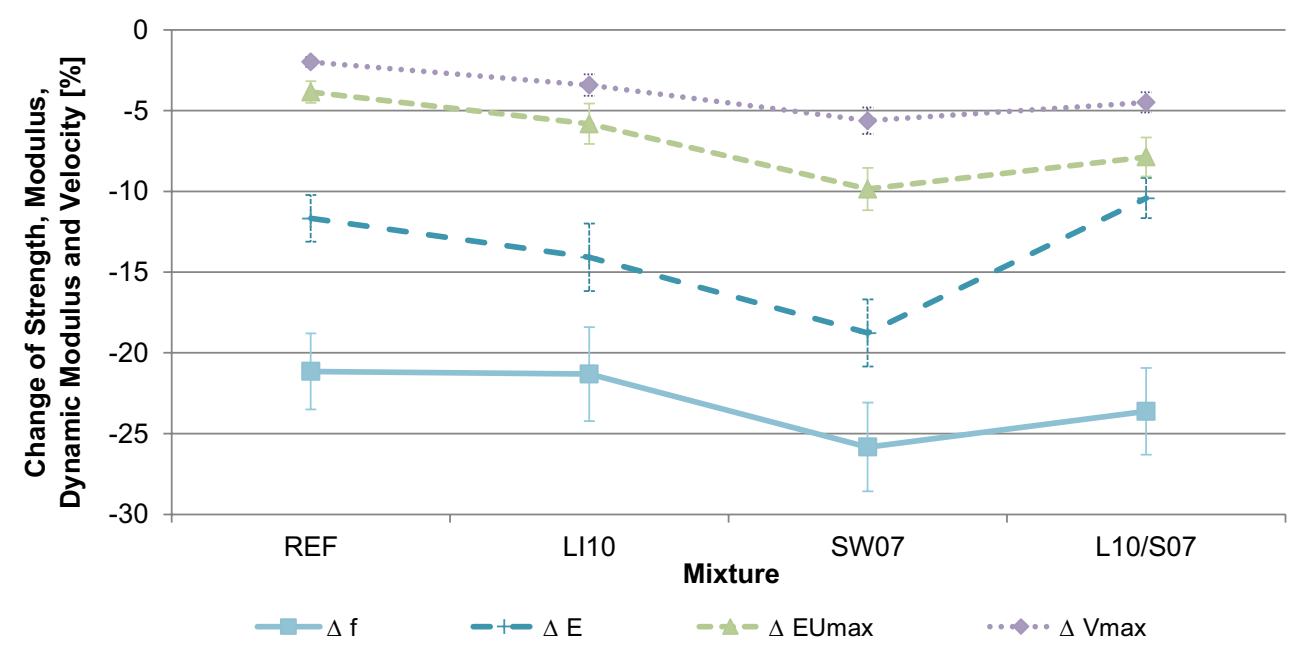

Fig. 18 Changes of parameters from measurement of ultrasonic pulse method and mechanical characteristics in cement-bonded particleboards during exposition to conditions in accordance with EN 321 
determination of percentage differences based on reduction of ultrasonic pulse velocity of dynamic Young's elasticity modulus between 4th or 5th and 10th cycle. The development of changes of parameters from ultrasonic pulse method is quite similar to development found by means of destructive testing of bending strength and modulus of elasticity in bending. This method of evaluating by ultrasonic pulse method gives a better characterization of current condition of cement-bonded particleboards during adverse exposition (wet-frost-dry cycles).

\section{Detailed analysis of structure}

Analysis of structure with an optical microscope supports mainly development of ultrasonic pulse velocity. Figures 19 and 20 show that most significant opening of cracks in the contact zone of cement matrix were observed in the direction of thickness after first

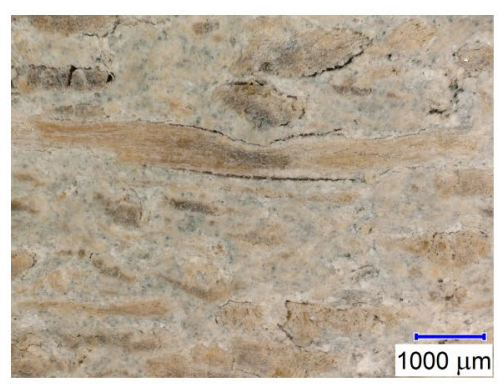

(a)

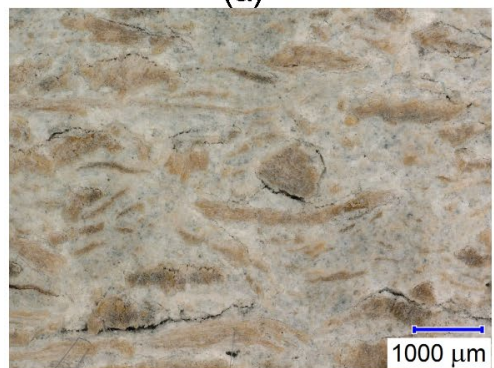

(d)

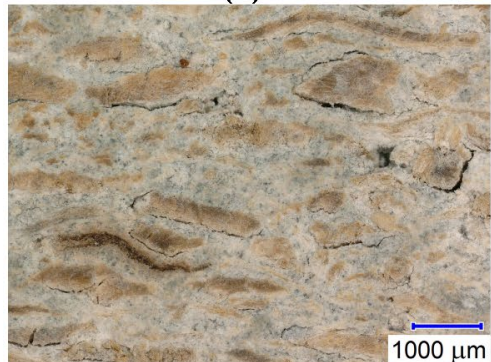

(g)

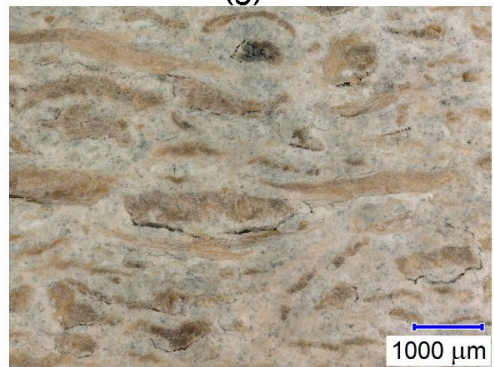

(j)

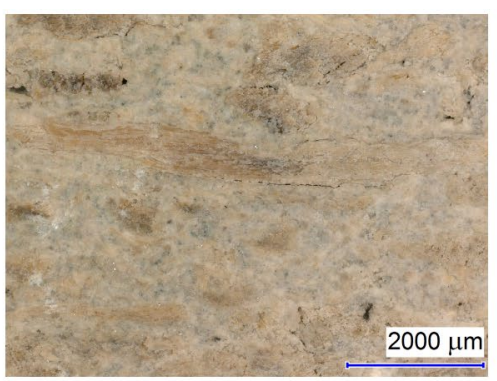

(b)

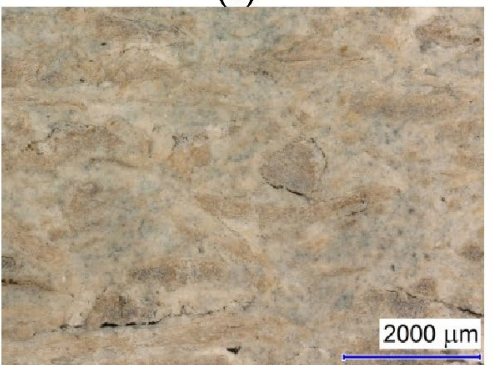

(e)

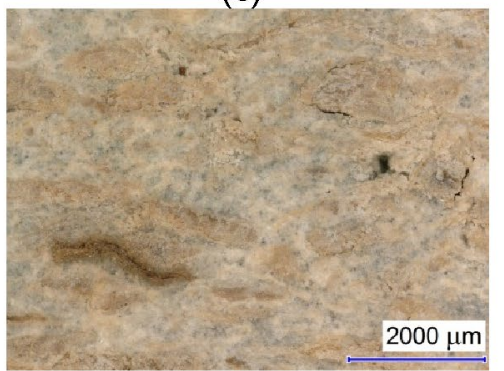

(h)

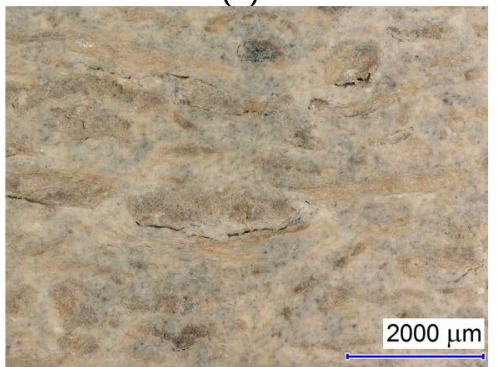

(k)

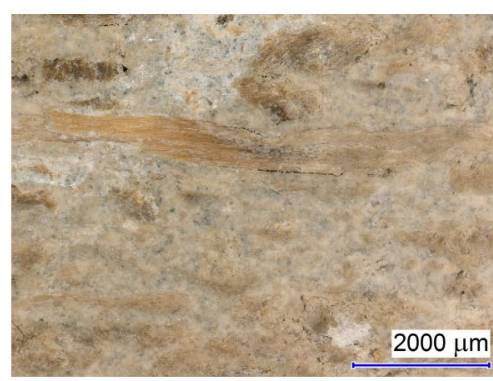

(c)

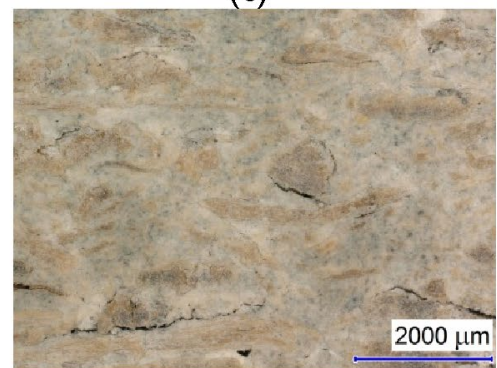

(f)

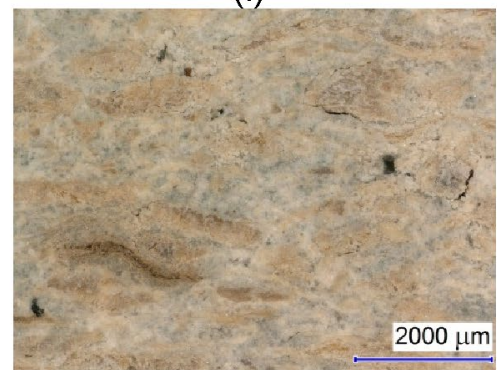

(i)

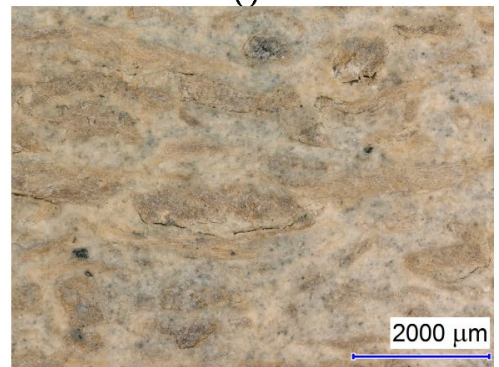

(l)

Fig. 19 Structure of boards REF: after a 1, b 5, c 10 cycles; LI10: after d 1, e 5, f 10 cycles; SW07: after g 1, h 5, i 10 cycles; L10/S07: after j 1, k 5, I 10 cycles in accordance with EN 321 (edge of the board, i.e. surface in the direction of thickness) 


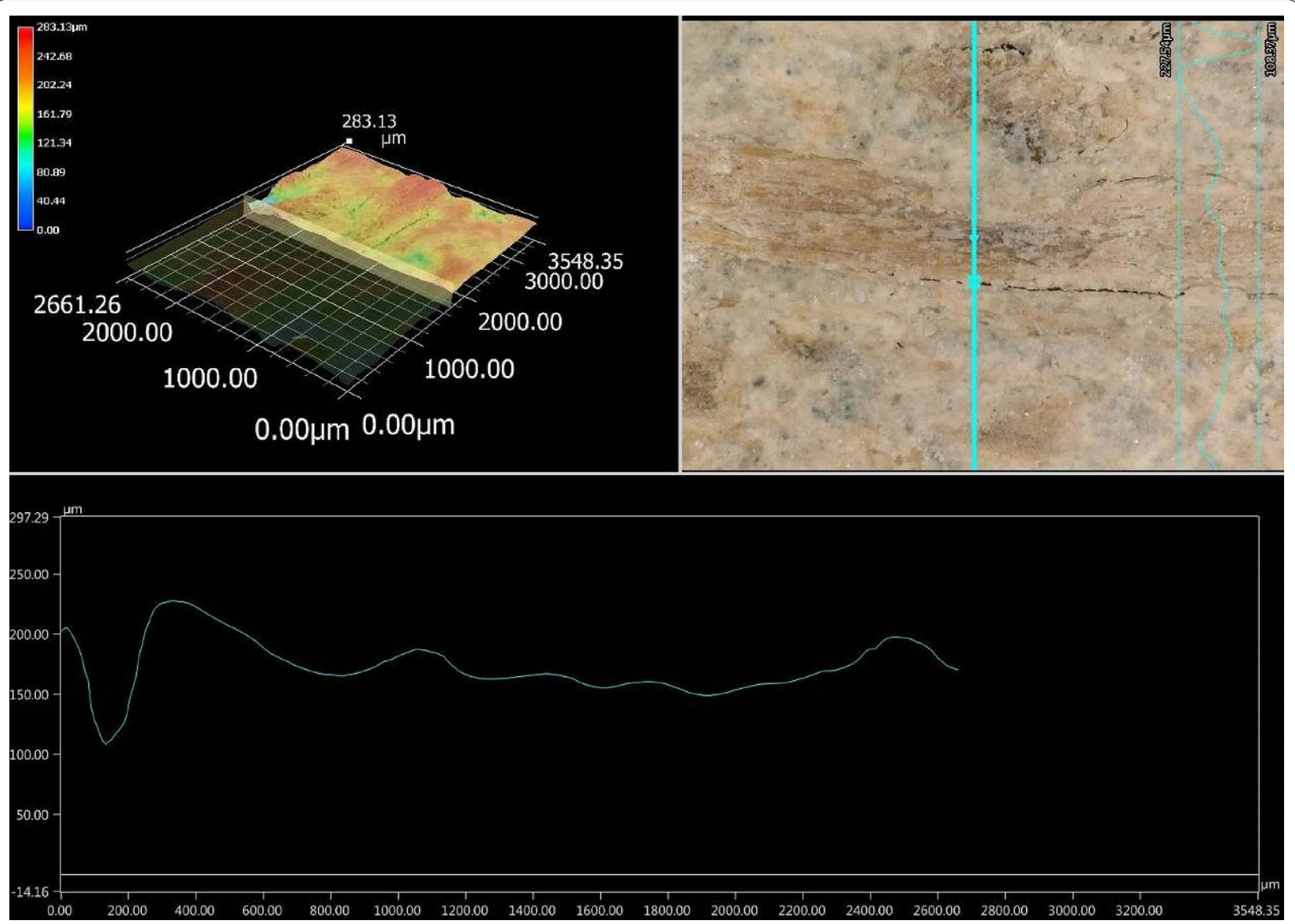

Fig. 20 Structure of REF boards - detailed evaluation of structure with analysis of relief of the surface after 5th wet-frost-dry cycle

wet-frost-dry cycle. Subsequently, influence of hysteresis of chips and crystallization of some ions contained in the cement matrix (for example $\mathrm{Ca}$ ) show. This gradually closes the structure of the boards and makes it more compact. Observed cracks are practically closed. However, after the 5th wet-frost-dry cycle, aggressiveness of environment prevails-sudden changes of temperature and humidity. Gradually, the contact zone of cement matrix and spruce chips is damaged. Failures are observed in the chips too. These facts cause slight decrease in ultrasonic pulse velocity from the 5th to 10 th wet-frost-dry cycle. Width of cracks gradually increases. Differences in the changes of structure of individual types of boards visible in the optical microscope images are not significant. This confirms minimal differences in development of changes in individual dimensions and volume of cement-bonded particleboards REF, LI10 and L10/S07.

Selected areas were analysed in 3D mode shown in Fig. 20, which makes it possible to evaluate structure of the relief; in this case it is related to changes in the direction of width of test specimens. Changes identified in the images confirm the results of dimensional and volumetric stability.

Figure 21 shows selected areas of top surface of the tested boards after finishing 10 wet-frost-dry cycles. Areas with cracks around the edges of the boards were selected intentionally. Identified cracks presented in Fig. 21 are beyond observation with the naked eye. Close observation shows only slight changes of shade. The microscope reveals presence of cracks. Leached or crystalized products were found in the cracks. This confirms the above-mentioned hypothesis that some substances leached from cement matrix form new phases. These new phases fill up the cracks formed by thermal and volumetric expansion/contraction, which creates more compact structure at first. Increasing expansion pressures then cause new failures, i.e. loss of bond between cement matrix and spruce chips. Swelling of wood can cause expansion pressures [81] which contribute to deterioration of the structure of cement-bonded particleboards.

An optical microscope can confirm or explain some phenomena which take place during exposure 


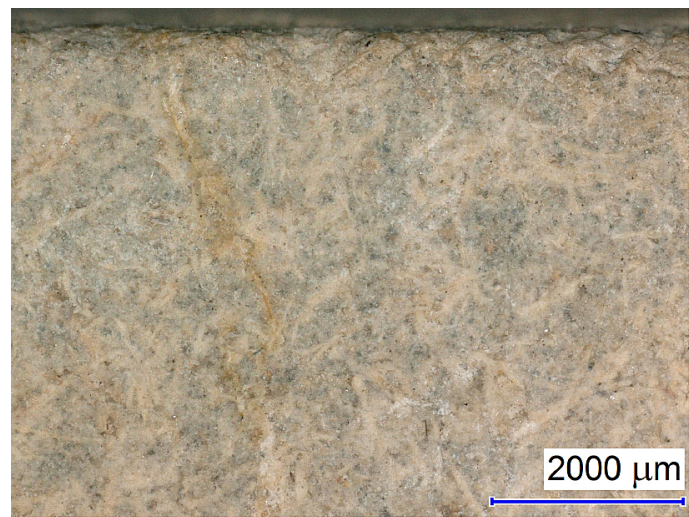

(a)

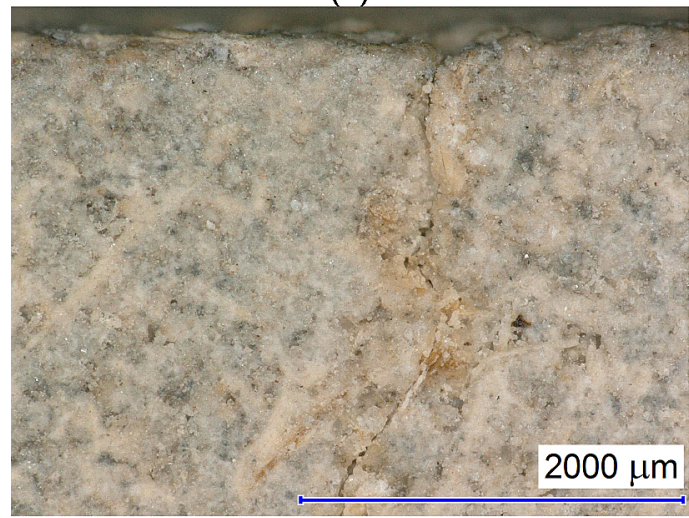

(c)

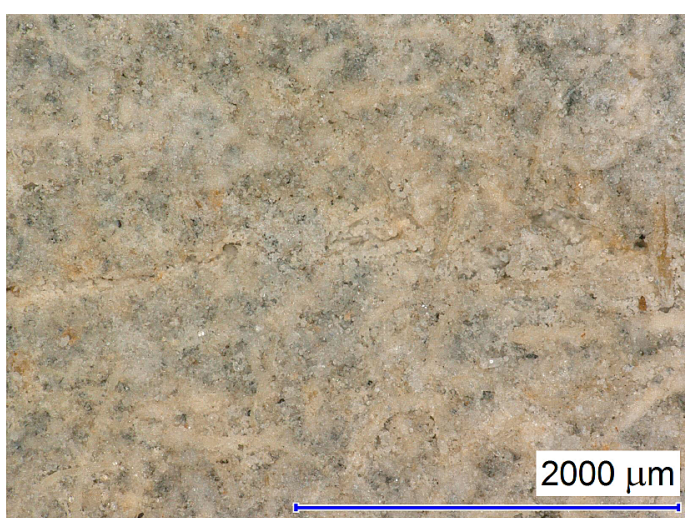

(b)

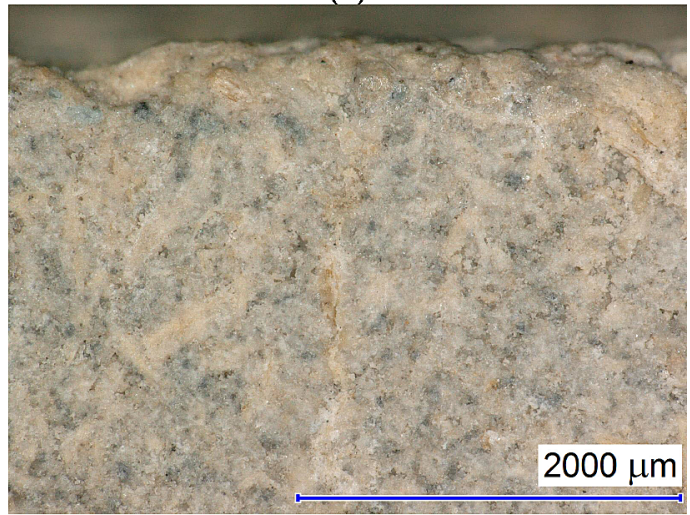

(d)

Fig. 21 Structure of boards after $10^{\text {th }}$ cycle according to EN 321: a REF, b LI10, c SW07 and d L10/S07

of cement-bonded particleboards to wet-frost-dry cycling. This method is capable of analysing contraction/expansion of wood chips which affect considerably dimensional and volumetric changes of cement-bonded particleboards.

\section{Conclusions}

Based on the results and findings including comparison with findings of other authors, it can be stated that wetfrost-dry cycling in accordance with EN 321 is reasonable for verification of cement-bonded particleboards durability. The exposition environment of this technical standard covers real conditions even though conditions described in EN 321 are more aggressive. Thus effect of adverse conditions on cement-bonded particleboards is significantly accelerated.

High level of relation was found between changes of ultrasonic pulse velocity and width of crack in the interface between cement matrix and wood chips. This finding also corresponds to dimensional or volumetric changes of the boards. Strength and modulus of elasticity strongly depend on composition of the boards. Positive effect of chips used as a secondary raw material on dimensional changes of cement-bonded particleboards caused by sudden changes of temperature and humidity was proved. Finely ground limestone contributes to more resistant structure of boards which leads to improved bending properties. Wet-frost-dry cycling had more influence on bending strength (decrease by $21 \%$ to $29 \%$ ) than on modulus of elasticity in bending (decrease by $12 \%$ to $19 \%$ ). Assumed possibility of using ultrasonic pulse method combined with an optical microscope for evaluation of changes of cement-bonded particleboards inner structure during sudden fluctuations in humidity and temperature was confirmed. Further research should focus on changes of structure during wet-frost-dry cycles also by other non-destructive methods-for example resonance (or impact-echo) method. Measuring values of electric impedance for determination of moist distribution in analysed material (during wet-frost-dry cycling), as presented in [82] could also bring crucial results and findings.

It was proved that modification of composition of cement-bonded particleboards with finely ground limestone and secondary chips is suitable from the point of 
view of resistance to adverse conditions. The cuttings could be re-used (partially or totally) for production of the boards. Simplicity of the cuttings modification (crushing, grain selection) creates good conditions for increasing economical effectiveness of production and follows current trends of environmental protection, i.e. re-using wastes from production as secondary raw materials.

\begin{abstract}
Abbreviations
REF: Reference cement-bonded particleboards; L110: Cement-bonded particleboards modified with finely ground limestone; SW07: Cement-bonded particleboards modified with secondary spruce chips; L10/S07: Cementbonded particleboards modified both limestone and secondary chips; TOC: Total organic carbon; V1, V2: Ultrasonic velocity; f0, f10: Strength in bending before and after wet-frost-dry cycles; E0, E10: Modulus of elasticity in bending before and after wet-frost-dry cycles; EU0, EU10: Modulus of elasticity in bending before and after wet-frost-dry cycles determined by ultrasonic impulse method; $\triangle \mathrm{f}, \triangle \mathrm{E}, \triangle \mathrm{EU}$ : Changes of strength and modulus of elasticity in bending after 10 wet-frost-dry cycles; PB: Particleboard; RH: Relative humidity; BUT: Brno University of Technology.
\end{abstract}

\section{Acknowledgements}

All tests and analyses were carried out at Brno University of Technology, Faculty of Civil Engineering, Institute of Technology of Building Materials and Components, and at AdMaS Centre.

\section{Authors' contributions}

Conceptualization, TM and MV; methodology, TM and JBr; validation, JBy, TM and JBr; formal analysis, JBy; investigation, TM and JBr; resources, TM; data curation, JBy and MV; writing-original draft preparation, TM; writing-review and editing, TM and JBy; visualization, TM; supervision, TM and JBy; project administration, TM and MV; funding acquisition, TM, JBy and MV. All authors read and approved the final manuscript.

\section{Funding}

Research presented in the article was funded by the Czech Science Foundation (GA ČR), project 19-00291S "Analysis of Processes during Forming the Structure in Silicate Composites with Organic Fillers and their Behaviour at Specific Conditions of Stress". This paper was also realized with the financial support from the national budget via the Ministry of Industry and Trade under the project FV30072 "Effective optimization of cement-bonded particleboards production waste utilization for manufacturing new competitive building materials".

\section{Availability of data and materials}

The datasets used and/or analysed during the current study are available from the corresponding author on reasonable request.

\section{Completing interests}

The authors declare that they have no competing interests.

\section{Author details}

${ }^{1}$ Brno University of Technology, Faculty of Civil Engineering, Institute of Technology of Building Materials and Components, Veveri 331/95, 60200 Brno, Czech Republic. ${ }^{2}$ CIDEM Hranice, a.s., Skalni 1088, 75301 Hranice, Czech Republic.

Received: 21 October 2021 Accepted: 1 December 2021

Published online: 04 January 2022

\section{References}

1. Fan MZ, Dinwoodie JM, Bonfield PW, Breese MC (1999) Dimensional instability of cement bonded particleboard: behaviour of wood chips from various stages of manufacture of CBPB. J Mater Sci 34:1729-1740. https:// doi.org/10.1023/A:1004590621247
2. Hossain MU, Wang L, Yu IKM, Tsang DCW, Poon C-S (2018) Environmental and technical feasibility study of upcycling wood waste into cementbonded particleboard. Constr Build Mater 173:474-480. https://doi.org/ 10.1016/j.conbuildmat.2018.04.066

3. Kochova K, Gauvin F, Schollbach K, Brouwers HJH (2020) Using alternative waste coir fibres as a reinforcement in cement-fibre composites. Constr Build Mater 231:117121. https://doi.org/10.1016/j.conbuildmat.2019. 117121

4. Fan M, Ndikontar MK, Zhou X, Ngamveng JN (2012) Cement-bonded composites made from tropical woods: compatibility of wood and cement. Constr Build Mater 36:135-140. https://doi.org/10.1016/j.conbu ildmat.2012.04.089

5. Soroushian P, Won J-P, Hassan M (2013) Durability and microstructure analysis of $\mathrm{CO}_{2}$-cured cement-bonded wood particleboard. Cement Concr Compos 41:34-44. https://doi.org/10.1016/j.cemconcomp.2013.04. 014

6. Nasser RA, Salem MZM, Al-Mefarrej HA, Aref IM (2016) Use of tree pruning wastes for manufacturing of wood reinforced cement composites. Cement Concr Compos 72:246-256. https://doi.org/10.1016/j.cemco ncomp.2016.06.008

7. Vasubabu M, Ramesh Babu NCH, Nagabhushanam O, Venkatesh RK (2018) Chemical treatment effect on mechanical properties of Haldina cordifolia wood species. Mater Today Proc 5(13):26424-26429. https://doi. org/10.1016/j.matpr.2018.08.096

8. Quiroga V, Marzocchi V, Rintoul I (2016) Influence of wood treatments on mechanical properties of wood-cement composites and of Populus Euroamericana wood fibers. Compos B Eng 84:25-32. https://doi.org/10. 1016/j.compositesb.2015.08.069

9. Sotannde OA, Oluwadare AO, Ogedoh O, Adeogun PF (2012) Evaluation of cement-bonded particle board produced from Afzelia Africana wood residues. J Eng Sci Tehcnol 7(6):732-743

10. Balčiūnas G, Pundienè I, Boris R, Kairytè A, Žvironaitè J, Gargasas J (2018) Long-term curing impact on properties, mineral composition and microstructure of hemp shive-cement composite. Constr Build Mater 188:326-336. https://doi.org/10.1016/j.conbuildmat.2018.08.126

11. Rana MN, Islam MN, Nath SK, Das AK, Ashaduzzaman Md, Shams MI (2019) Properties of low-density cement-bonded composite panels manufactured from polystyrene and jute stick particles. J Wood Sci 65:53. https://doi.org/10.1186/s10086-019-1831-3

12. Olorunnisola AO (2005) Dimensional stability of cement-bonded composite boards produced from rattan cane particles. J Bamboo Rattan 4(2):173-182

13. Ashori A, Tabarsa T, Azizi K, Mirzabeygi R (2011) Wood-wool cement board using mixture of eucalypt and poplar. Ind Crop Prod 34(1):11461149. https://doi.org/10.1016/j.indcrop.2011.03.033

14. Odeyemi SO, Abdulwahab R, Adeniyi AG, Atoyebi OD (2020) Physical and mechanical properties of cement-bonded particle board produced from African balsam tree (Populous Balsamifera) and periwinkle shell residues. Results Eng 6:100-126. https://doi.org/10.1016/j.rineng.2020.100126

15. Olorunnisola AO, Adefisan $\mathrm{OO}$ (2002) Trial production and testing of cement-bonded particleboard from rattan furniture waste. Wood Fiber Sci 34(1):116-124. https://doi.org/10.1163/1569159054699308

16. Ezerskiy V, Kuznetsova NV, Seleznev AD (2018) Evaluation of the use of the CBPB production waste products for cement composites. Constr Build Mater 190:1117-1123. https://doi.org/10.1016/j.conbuildmat.2018.09.148

17. Melichar T, Bydzovsky J, Dufka A (2019) Seldom used by-product from trimming cement-bonded particleboard shows potential for modifying building materials composition. Waste Forum 4:368-377

18. Melichar T, Bydzovsky J (2019) Influence of dust waste containing a silicate matrix and organic filler on properties of cement composites [Vliv prachového odpadu s obsahem silikátové matrice a organického plniva na vlastnosti cementových kompozitů]. Waste Forum 4:378-390

19. Caprai V, Gauvin F, Schollbach K, Brouwers HJH (2018) Influence of the spruce strands hygroscopic behaviour on the performances of woocement composites. Constr Build Mater 166:522-530. https://doi.org/10. 1016/j.conbuildmat.2018.01.162

20. Peng Y, Han Y, Gardner DJ (2010) Sodium silicate coated wood. In: Proceedings of the International Convention of Society of Wood Science and Technology and United Nations Economic Commission for EuropeTimber Committee, Geneva, Switzerland. October 11-14, 2010. Paper WS-59:1-9. 
21. Christensen GN, Kelsey KE (1959) Die Sorption von Wasserdampf durch die chemischen Bestandteile des Holzes. Holz Roh Werkst 17:189-203

22. Lee SH, Ashaari Z, Ang AF, Halip JA (2017) Dimensional stability of heat oil-cured particleboard made with oil palm trunk and rubberwood. Eur J Wood Prod 75:285-288. https://doi.org/10.1007/s00107-016-1110-6

23. Sandberg D, Kutnar A (2016) Thermally modified timber: recent developments in Europe and North America. Wood Fiber Sci 48:28-38

24. Ahmed SA, Morén T, Sehlstedt-Persson M, Blom A (2017) Effect of oil impregnation on water repellency, dimensional stability and mold susceptibility of thermally modified European aspen and downy birch wood. J Wood Sci 63:74-82. https://doi.org/10.1007/s10086-016-1595-y

25. Fu Z, Zhou Y, Gao X, Liu H, Zhou F (2019) Changes of water related properties in radiata pine wood due to heat treatment. Constr Build Mater 227:116692. https://doi.org/10.1016/j.conbuildmat.2019.116692

26. Li T, Cheng D, Avramidis S, Wålinder MEP, Zhou D (2017) Response of hygroscopicity to heat treatment and its relation to durability of thermally modified wood. Constr Build Mater 144:671-676. https://doi.org/ 10.1016/j.conbuildmat.2017.03.218

27. Popescu M-C, Froidevaux J, Navi P, Popescu C-M (2013) Structural modifications of Tilia cordata wood during heat treatment investigated by FT-IR and 2D IR correlation spectroscopy. J Mol Struct 1033:176-186. https:// doi.org/10.1016/j.molstruc.2012.08.035

28. He Z, Qian J, Qu L, Yan N, Yi S (2019) Effects of Tung oil treatment on wood hygroscopicity, dimensional stability and thermostability. Ind Crops Prod 140:111647. https://doi.org/10.1016/j.indcrop.2019.111647

29. Fan MZ, Dinwoodie JM, Bonfield PW, Breese MC (2002) Dimensional instability of cement bonded particleboard: Part 1. Behaviour and modelling prediction under a constant and single change in $\mathrm{RH}$. Wood Sci Technol 36:125-143. https://doi.org/10.1007/s002260100110

30. Fan MZ, Dinwoodie JM, Bonfield PW, Breese MC (2004) Dimensional instability of cement bonded particleboard: Part 2: Behaviour and its prediction under cyclic changes in RH. Wood Sci Technol 38:53-68. https:// doi.org/10.1007/s00226-003-0208-2

31. Fan MZ, Bonfield PW, Dinwoodie JM, Boxall J, Breese MC (2004) Dimensional instability of cement bonded particleboard: the effect of surface coating. Cem Concr Res 34:1189-1197. https://doi.org/10.1016/j.cemco nres.2003.12.010

32. Bekhta P, Niemz P (2003) Effect of high temperature on the change in color, dimensional stability and mechanical properties of spruce wood. Holzforschung 57:539-546. https://doi.org/10.1515/HF.2003.080

33. Tjeerdsma BF, Militz H (2005) Chemical changes in hydrothermal treated wood: FTIR analysis of combined hydrothermal and dry heattreated wood. Holz Roh Werkst 63:102-111. https://doi.org/10.1007/ s00107-004-0532-8

34. Fuwape JA, Fabiyi JS, Osuntuyi EO (2007) Technical assessment of three layered cement-bonded boards produced from wastepaper and sawdust. Waste Manage 27(11):1611-1616. https://doi.org/10.1016/j.wasman. 2006.09.005

35. Chen L, Beall FC (2000) Monitoring bond strength development in particleboard during pressing using acousto-ultrasonics. Wood Fiber Sci 32(4):466-477

36. Kawamoto S, Williams RS (2002) Acoustic emission and acousto-ultrasonic techniques for wood and wood-based composites-A review. Gen Tech. Rep. FPL-GTR-134. U.S. Department of Agriculture, Forest Service, Forest Products Laboratory, Madison, Wl. $16 \mathrm{p}$.

37. Bekhta P, Niemz P, Kucera LJ (2002) The influence of selected variables on sound propagation in reconstituted wood-based materials. Eur J Wood Wood Prod 60:41-45. https://doi.org/10.1007/s00107-001-0267-8

38. Lin HC, Fujimoto Y, Murase $Y$ (2000) Characteristic of ultrasonic wave transmission in particleboard. In: 5th Pacific Rim Rio-Based Composites Symposium, Canberra. December 10-13, 2000. pp 478-484.

39. Chen L, Beall FC (2000) Monitoring bond strength development in particleboard during pressing, using acousto-ultrasonics. Wood Fiber Sci 32:466-477

40. Hilbers U, Thömen H, Hasener J, Frühwald A (2011) Effects of material density and particle type on the ultrasonic transmission through woodbased panels. Wood Sci Technol 46:685-698. https://doi.org/10.1007/ s00226-011-0436-9

41. Schmerr LW, Song SJ (2007) Ultrasonic nondestructive evaluation systems models and measurements. Springer, New York. https://doi.org/10.1007/ 978-0-387-49063-2
42. Kazemi S, Bucur V, Ebrahimi G (2005) Elastic constants of particleboard with ultrasonic technique. Mater Lett 59:2039-2042. https://doi.org/10. 1016/j.matlet.2005.02.013

43. Lin HC, Fujimoto Y, Murase Y (2002) Influences of particle size and moisture content on ultrasonic wave transmission characteristics in thickness direction of particleboard. J Fac Agric Kyushu Univ 46:433-444

44. Sanabria SJ, Hilbers U, Neuenschwander J, Niemz P, Sennhauser U, Thömen H, Wenker JL (2013) Modeling and prediction of density distribution and microstructure in particleboards from acoustic properties by correlation of non-contact high-resolution pulsed air-coupled ultrasound and X-ray images. Ultrasonics 53:157-170. https://doi.org/10.1016/j.ultras. 2012.05.004

45. Hilbers U, Thoemen H, Hasener J, Fruehwald A (2012) Effects of panel density and particle type on the ultrasonic transmission through woodbased panels. Wood Sci Technol 46:685-698. https://doi.org/10.1007/ s00226-011-0436-9

46. Chen L, Beall CF (2000) Monitoring bond strength development in particleboard during pressing, using acousto-ultrasonics. Wood Fiber Sci 32(4):466-477

47. Bekhta PA, Niemz P, Kucera L (2000) The study of sound propagation in the wood-based composite materials. In: Proceedings of the 12th international symposium on nondestructive of wood, Sopron. September 13-15, 2000, pp 33-41

48. Vun RY, Wu Q, Bhardwaj MC, Stead G (2003) Ultrasonic characterization of structural properties of oriented strandboard: a comparison of directcontact and non-contact methods. Wood Fiber Sci 35(3):381-396

49. Saadat-Nia MA, Brancheriau L, Gallet P, Enayati AA, Pourtahmasi K, Honar$\operatorname{var} F$ (2011) Ultrasonic wave parameter changes during propagation through poplar and spruce reaction wood. BioResources 6(2):1172-1185. https://doi.org/10.15376/biores.6.2.1172-1185

50. Melichar T, Bydžovský J, Černý V (2014) Effect of modification of cementbonded particleboards composition on their frost resistance. Adv Mater Res 897:184-187. https://doi.org/10.4028/www.scientific.net/AMR.897. 184

51. Frybort S, Mauritz R, Teischinger U, Müller U (2008) Cement bonded composites - a mechanical review. BioResources 3:602-626

52. Ahn WY, Moslemi AA (1980) SEM examination of wood-Portland cement bonds. Wood Sci 13:77-82

53. Bejó L, Takáts P, Vass N (2005) Development of cement bonded composite beams. Acta Silv Lign Hung 1:111-119

54. Coutts RSP, Kightly P (1984) Bonding in wood fibre-cement composites. J Mater Sci 19:3355-3359

55. Parameswaran N, Bröker FW, Simatupang MH (1977) Zur Mikrotechnologie mineralgebundener Holzwerkstoffe Holzforschung 31:173-178 (In German)

56. Dewitz K, Kuschy B, Otto T (1984) Stofftransporte bei der Abbindung zementgebundener Holzwerkstoffe. Holztechnologie 3:151-154 (In German)

57. Miller DP, Moslemi AA (1991) Wood-cement composites: effect of model compounds on hydration characteristics and tensile strength. Wood Fibre Sci 23:472-482

58. Thomas NL, Birchall JD (1983) Retarding action of sugars on cement hydration. Cement Concrete Res 13(6):830-842. https://doi.org/10.1016/ 0008-8846(83)90084-4

59. Tittelein P, Cloutier A, Bissonnette B (2012) Design of a low-density wood-cement particleboard for interior wall finish. Cement Concrete Comp 34(2):218-222. https://doi.org/10.1016/j.cemconcomp.2011.09.020

60. Fischer F, Wienhaus O, Ryssel M, Olbrech J (1974) Die wasserlöslichen kohlenhydrate des holzes und ihr einfluss auf die herstellung von holzwolle-leichtauplatten. Holztechnologie 15(1):12-19 (In German)

61. Wei YM, Tomita B, Hiramatsu Y, Miyatake A, Fujii T, Fujii T, Yoshinaga S (2003) Hydration behavior and compressive strength of cement mixed with exploded wood fiber strand obtained by the water-vapor explosion process. J Wood Sci 49:317-326

62. Schubert B, Wienhaus O, Bloßfeld O (1990a) Untersuchungen zum System Holz-Zement. Einfluß unterschiedlicher Zementarten auf das Abbindeverhalten von Holz-Zement-Mischungen. Holz Roh Werkst 48(5):185-189 (In German)

63. Schwarz HG, Simatupang MH (1983) Einfluß der chemischen Zusammensetzung von Portlandzement auf die Druckfestigkeit von Versuchskörpern 
aus Zement und Fichten- oder Buchenspänen. Holz Roh Werkst 41:65-69 (In German)

64. Schwarz HG (1989) Cement-bonded board in Malaysia. In: Moslemi AA (ed) Fiber and Particleboards Bonded with Inorganic Binders. Forest Products Research Society, Madison, Wisconsin, pp 91-93

65. Sudin R, Swamy N (2006) Bamboo and wood fibre cement composites for sustainable infrastructure regeneration. J Mater Sci 41:6917-6924. https://doi.org/10.1007/s10853-006-0224-3

66. Yel H, Cavdar AD, Torun SB (2020) Effect of press temperature on some properties of cement bonded particleboard. Maderas Ciencia y technología 22(1):83-92. https://doi.org/10.4067/S0718-221X2020005000108

67. EN 634-1 (1995) Cement-bonded particleboards—specification—Part 1: general requirements. CEN

68. EN 634-2 (2007) Cement-bonded particleboards-specifications-Part 2: requirements for OPC bonded particleboards for use in dry, humid and external conditions. CEN

69. EN 323 (1993) Wood-based panels. Determination of density. CEN

70. EN 310 (1993) Wood based panels. Determination of modulus of elasticity in bending and of bending strength. CEN

71. EN 321 (2001) Wood-based panels_-determination of moisture resistance under cyclic test conditions. CEN

72. EN 12504-4 (2004) Testing concrete-Part 4: determination of ultrasonic pulse velocity. CEN

73. ČSN 731371 (2011) Non-destructive testing of concrete-method of ultrasonic pulse testing of concrete. ČNI

74. Rowell RM (2005) Chemical modification of wood. In: Rowell RM (ed) Handbook of wood chemistry and wood composites. CRC Press, Boca Raton, pp 381-420

75. Karlsson O, Torniainen P, Dagbro O, Granlund K, More'n T (2012) Presence of water-soluble compounds in thermally modified wood: carbohydrates and furfurals. BioResources 7(3):3679-3689

76. Černý V (2015) Quality of the structure of ash bodies based on different types of ash. Mater Technol 49(4):601-605. https://doi.org/10.17222/mit. 2014.207

77. Melichar J, Drochytka R, Černý V (2014) Experimental testing of hydroinsulating injection screens. Adv Mater Res 860-863:2327-2330. https://doi. org/10.4028/www.scientific.net/AMR.860-863.2327

78. Makhloufi Z, Chettih M, Bederina M, El HK, Bouhicha M (2015) Effect of quaternary cementitious systems containing limestone, blast furnace slag and natural pozzolan on mechanical behavior of limestone mortars. Constr Build Mater 95:647-657. https://doi.org/10.1016/j.conbuildmat. 2015.07.050

79. Oey T, Kumar A, Bullard JW, Neithalath N, Sant G (2013) The filler effect: the influence of filler content and surface area on cementitious reaction rates. J Am Ceram Soc 96(6):1978-1990. https://doi.org/10.1111/jace. 12264

80. Rahhal V, Bonavetti V, Trusilewicz L, Pedrajas C, Talero R (2012) Role of the filler on Portland cement hydration at early ages. Constr Build Mater 27(1):82-90. https://doi.org/10.1016/j.conbuildmat.2011.07.021

81. Rowell RM (2004) Solid wood processing chemical modification. In: Burley J (ed) Encyclopedia of forest sciences. Elsevier Ltd., Amsterdam, pp 1269-1274

82. Peterková J, Sedlmajer M, Michalčíková M, Pařilková J (2019) Electrical impedance used for measurement of moisture distribution in thermal insulation plasters. Periodica Polytechnica Civil Eng 63(2):489-498. https://doi.org/10.3311/PPci.10901

\section{Publisher's Note}

Springer Nature remains neutral with regard to jurisdictional claims in published maps and institutional affiliations.

\section{Submit your manuscript to a SpringerOpen ${ }^{\circ}$ journal and benefit from:}

- Convenient online submission

- Rigorous peer review

- Open access: articles freely available online

- High visibility within the field

- Retaining the copyright to your article

Submit your next manuscript at $\boldsymbol{\nabla}$ springeropen.com 